Prepared in cooperation with the Lac du Flambeau Band of Lake Superior Chippewa and Indian Health Service

\title{
Simulation of Groundwater Flow and Interaction of Groundwater and Surface Water on the Lac du Flambeau Reservation, Wisconsin
}

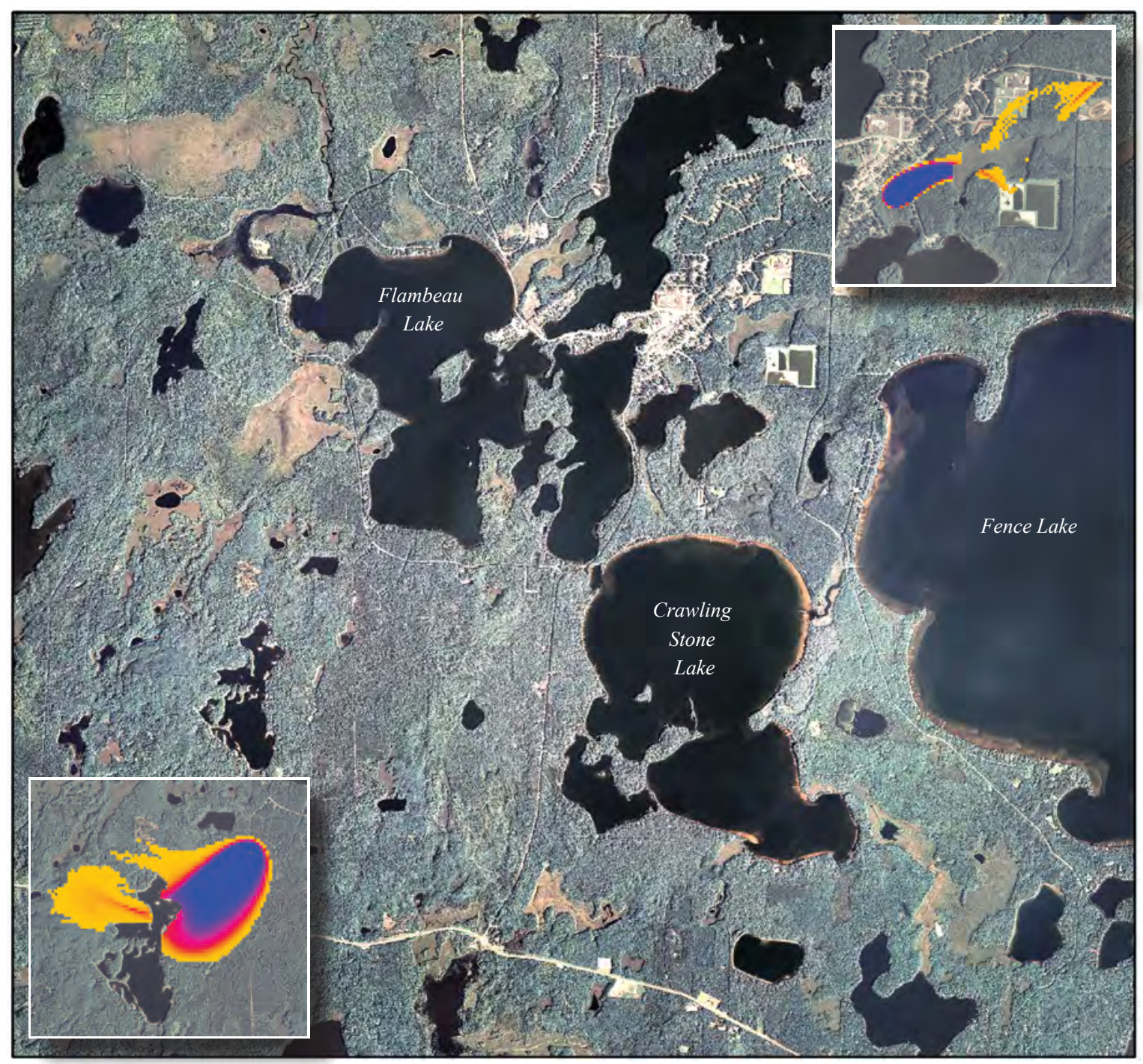

Scientific Investigations Report 2014-5020 
Cover: Aerial photograph of central Lac du Flambeau Reservation, with inset maps showing the areal probability of capturing groundwater recharged at the water table for pumped high-capacity wells on the Reservation. 


\section{Simulation of Groundwater Flow and Interaction of Groundwater and Surface Water on the Lac du Flambeau Reservation, Wisconsin}

By Paul F. Juckem, Michael N. Fienen, and Randall J. Hunt

Prepared in cooperation with the Lac du Flambeau Band of Lake Superior

Chippewa and Indian Health Service

Scientific Investigations Report 2014-5020 


\title{
U.S. Department of the Interior SALLY JEWELL, Secretary
}

\section{U.S. Geological Survey Suzette M. Kimball, Acting Director}

\author{
U.S. Geological Survey, Reston, Virginia: 2014
}

For more information on the USGS - the Federal source for science about the Earth, its natural and living resources, natural hazards, and the environment, visit http://www.usgs.gov or call 1-888-ASK-USGS.

For an overview of USGS information products, including maps, imagery, and publications, visit http://www.usgs.gov/pubprod

To order this and other USGS information products, visit http://store.usgs.gov

Any use of trade, firm, or product names is for descriptive purposes only and does not imply endorsement by the U.S. Government.

Although this information product, for the most part, is in the public domain, it also may contain copyrighted materials as noted in the text. Permission to reproduce copyrighted items must be secured from the copyright owner.

Suggested citation:

Juckem, P.F., Fienen, M.F., Hunt, R.J., 2014, Simulation of groundwater flow and interaction of groundwater and surface water on the Lac du Flambeau Reservation, Wisconsin, U.S. Geological Survey Scientific Investigations Report 2014-5020, 34 p., http://dx.doi.org/10.3133/sir20145020.

ISSN 2328-0328 (online)

http://dx.doi.org/10.3133/sir20145020 


\section{Contents}

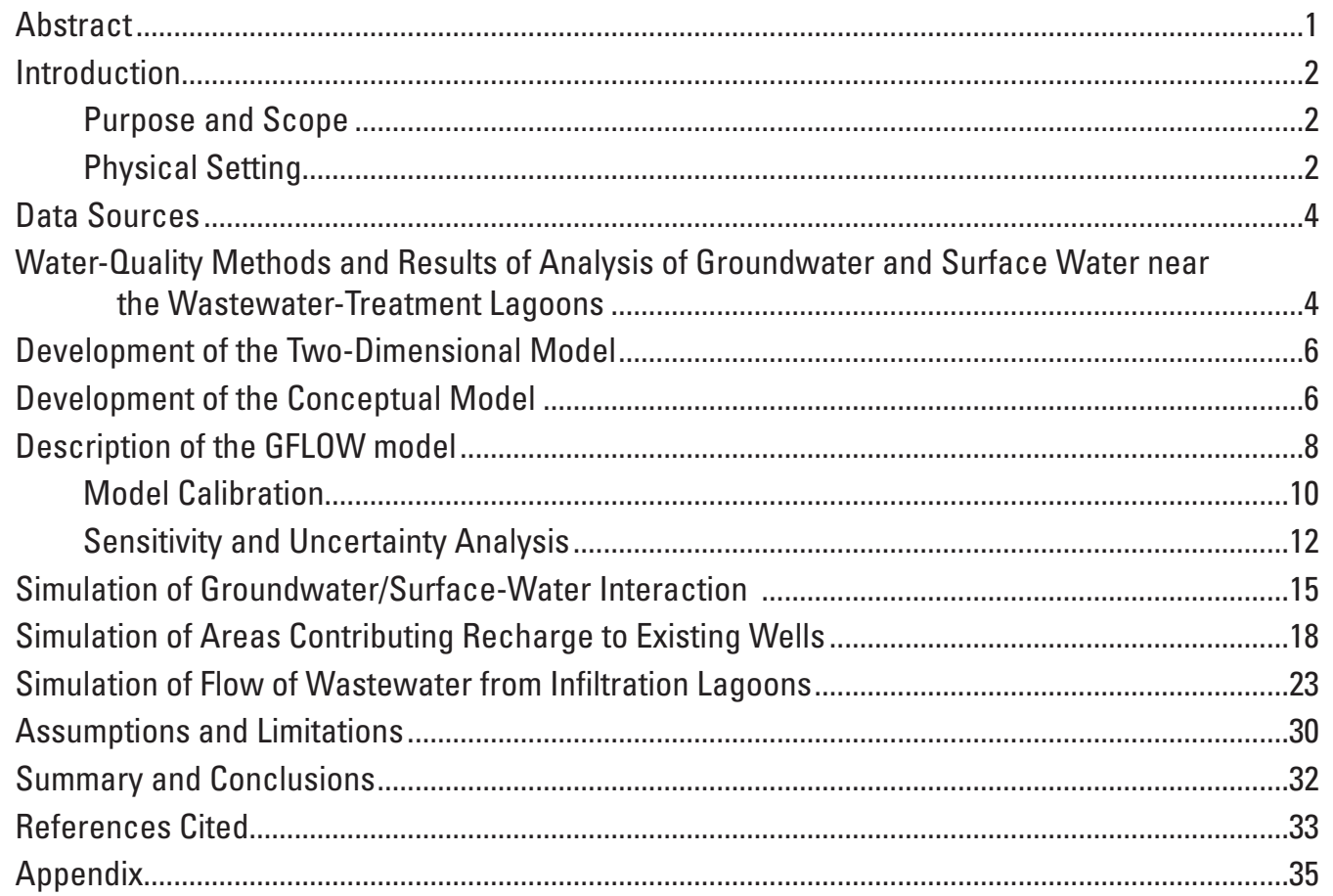

\section{Figures}

1. Map showing location of the Lac du Flambeau Reservation and streamflowmeasurement sites, in Iron and Vilas Counties, Wisconsin ...

2. Map showing location of wastewater-treatment lagoons, well nest sampling sites, and surface-water sampling sites, Lac du Flambeau Reservation, Wisconsin

3. Diagram showing cross section $A-A^{\prime}$ of the conceptual model of groundwater flow, Lac du Flambeau Reservation, Wisconsin.

4. Map showing hydrologic features simulated with analytic elements, Lac du Flambeau Reservation, Wisconsin

5. Graph showing simulated water levels in relation to target water levels, Lac du Flambeau Reservation, Wisconsin

6. Map showing simulated groundwater flow directions and computed difference between simulated and target water levels and base flows, Lac du Flambeau Reservation, Wisconsin

7. Diagram of the hydrologic cycle for the northeastern part of the Lac du Flambeau Reservation, Wisconsin

8. Map showing simulated area contributing recharge to wells pumped at the current (2010) average rate at the Main Pumphouse site and the probability of capture for particles of water recharging the water table, Lac du Flambeau Reservation, Wisconsin 
9. Map showing simulated area contributing recharge to wells pumped at the expected future rate at the Main Pumphouse site and the probability of capture for particles of water recharging the water table, Lac du Flambeau Reservation, Wisconsin

10. Map showing simulated area contributing recharge to wells pumped at the current (2010) average rate at the West Pumphouse site and the probability of capture for particles of water recharging the water table, Lac du Flambeau Reservation, Wisconsin

11. Map showing simulated area contributing recharge to wells pumped at the expected future rate at the West Pumphouse site and the probability of capture for particles of water recharging the water table, Lac du Flambeau Reservation, Wisconsin

12. Map showing simulated probability of the plume extent from the wastewatertreatment lagoons under current (2010) conditions, Lac du Flambeau Reservation, Wisconsin

13. Map showing simulated probability of the plume extent for a scenario with waste water discharged through a 100 -foot-long diffuser 10 feet beneath a wetland east of Moss Lake, Lac du Flambeau Reservation, Wisconsin.

14. Map showing simulated probability of the plume extent for a scenario with wastewater discharged to Mindy Lake, Lac du Flambeau Reservation, Wisconsin

15. Map showing simulated probability of the plume extent for a scenario with wastewater discharged from a hypothetical infiltration lagoon south of the current lagoons, Lac du Flambeau Reservation, Wisconsin...

16. Map showing simulated probability of the plume extent for a scenario with wastewater discharged from a hypothetical infiltration lagoon northeast of the current lagoons, Lac du Flambeau Reservation, Wisconsin

17. Maps showing simulated groundwater flow paths from the wastewatertreatment lagoon area $(A)$ with current $(2010)$ wastewater infiltration rates and $(B)$ zero infiltration at the lagoons, Lac du Flambeau Reservation, Wisconsin...

\section{Tables}

1. Calibrated parameter values and composite sensitivities for the analytic element model of the Lac du Flambeau Reservation, Wisconsin.

2A. Calibration results for groundwater and lake level targets and associated weights used for calibration with the parameter-estimation program PEST, Lac du Flambeau Reservation, Wisconsin

2B. Calibration results for stream base-flow targets and associated weights used for calibration with the parameter estimation program PEST, Lac du Flambeau Reservation, Wisconsin

3. Simulated lake water budgets for the calibrated model and wet and dry scenarios in Lac du Flambeau, Wisconsin. 


\section{Conversion Factors}

Inch/Pound to International System of Units

\begin{tabular}{|c|c|c|}
\hline Multiply & By & To obtain \\
\hline \multicolumn{3}{|c|}{ Length } \\
\hline inch (in.) & 2.54 & centimeter $(\mathrm{cm})$ \\
\hline foot $(\mathrm{ft})$ & 0.3048 & meter $(\mathrm{m})$ \\
\hline mile (mi) & 1.609 & kilometer $(\mathrm{km})$ \\
\hline \multicolumn{3}{|c|}{ Area } \\
\hline square mile $\left(\mathrm{mi}^{2}\right)$ & 2.590 & square kilometer $\left(\mathrm{km}^{2}\right)$ \\
\hline \multicolumn{3}{|c|}{ Flow rate } \\
\hline foot per day (ft/d) & 0.3048 & meter per day $(\mathrm{m} / \mathrm{d})$ \\
\hline foot per year (ft/yr) & 0.3048 & meter per year (m/yr) \\
\hline cubic foot per second $\left(\mathrm{ft}^{3} / \mathrm{s}\right)$ & 0.02832 & cubic meter per second $\left(\mathrm{m}^{3} / \mathrm{s}\right)$ \\
\hline cubic foot per day $\left(\mathrm{ft}^{3} / \mathrm{d}\right)$ & 0.02832 & cubic meter per day $\left(\mathrm{m}^{3} / \mathrm{d}\right)$ \\
\hline gallon per minute (gal/min) & 0.06309 & liter per second $(\mathrm{L} / \mathrm{s})$ \\
\hline inch per hour (in/h) & 0.0254 & meter per hour $(\mathrm{m} / \mathrm{h})$ \\
\hline inch per year (in/yr) & 25.4 & millimeter per year (mm/yr) \\
\hline \multicolumn{3}{|c|}{ Hydraulic conductivity } \\
\hline foot per day (ft/d) & 0.3048 & meter per day $(\mathrm{m} / \mathrm{d})$ \\
\hline \multicolumn{3}{|c|}{ Transmissivity* } \\
\hline foot squared per day (ft2/d) & 0.09290 & meter squared per day $\left(\mathrm{m}^{2} / \mathrm{d}\right)$ \\
\hline
\end{tabular}

Temperature in degrees Fahrenheit $\left({ }^{\circ} \mathrm{F}\right)$ may be converted to degrees Celsius $\left({ }^{\circ} \mathrm{C}\right)$ as follows: ${ }^{\circ} \mathrm{C}=\left({ }^{\circ} \mathrm{F}-32\right) / 1.8$

Vertical coordinate information is referenced to the North American Vertical Datum of 1988 (NAVD 88).

Horizontal coordinate information is referenced to North American Datum of 1927 (NAD 27).

Elevation, as used in this report, refers to distance above the vertical datum.

*Transmissivity: The standard unit for transmissivity is cubic foot per day per square foot times foot of aquifer thickness $\left[\left(\mathrm{ft}^{3} / \mathrm{d}\right) / \mathrm{ft}^{2}\right] \mathrm{ft}$. In this report, the mathematically reduced form, foot squared per day $\left(\mathrm{ft}^{2} / \mathrm{d}\right)$, is used for convenience.

Specific conductance is given in microsiemens per centimeter at 25 degrees Celsius $\left(\mu \mathrm{S} / \mathrm{cm}\right.$ at $\left.25^{\circ} \mathrm{C}\right)$.

Concentrations of chemical constituents in water are given either in milligrams per liter (mg/L) or micrograms per liter $(\mu \mathrm{g} / \mathrm{L})$. 


\section{Acknowledgments}

\section{Local Project Coordinator}

Gretchen Watkins, Water Resource Specialist, Lac du Flambeau Band of Lake Superior Chippewa, Lac du Flambeau, Wisconsin.

Matthew Zoch, Field engineer, Indian Health Service, Rhinelander, Wis.

\section{Field Support}

James Rauman, Hydrologic Technician, U.S. Geological Survey, Middleton, Wis.

Jason Smith, Hydrologic Technician, U.S. Geological Survey, Middleton, Wis.

Brent Olson, Lead Hydrologic Technician, U.S. Geological Survey, Rhinelander, Wis.

\section{Publishing Support}

Leah Kammel, Hydrologist, U.S. Geological Survey Wisconsin Water Science Center, Middleton, Wis.

Michelle Greenwood, Reports Specialist, U.S. Geological Survey Wisconsin Water Science Center, Middleton, Wis.

Rosemary Stenback, Visual Information Specialist, U.S. Geological Survey, Science Publishing Network, Madison, Wis.

\section{Technical Reviewers}

Charles Dunning, Groundwater Specialist, U.S. Geological Survey Wisconsin Water Science Center, Middleton, Wis.

Stanley Leake, Research Hydrologist, U.S. Geological Survey Arizona Water Science Center, Tucson, Ariz.

\section{Editorial Reviewer}

Ruth Larkins, Editor, Science Publishing Network, West Trenton, New Jersey

\section{Approving Official}

Kevin Breen, Bureau Approving Official, U.S. Geological Survey Office of Science Quality and Integrity, New Cumberland, Pennsylvania 


\title{
Simulation of Groundwater Flow and Interaction of Groundwater and Surface Water on the Lac du Flambeau Reservation, Wisconsin
}

\author{
By Paul F. Juckem, Michael N. Fienen, and Randall J. Hunt
}

\section{Abstract}

The Lac du Flambeau Band of Lake Superior Chippewa and Indian Health Service are interested in improving the understanding of groundwater flow and groundwater/surfacewater interaction on the Lac du Flambeau Reservation (Reservation) in southwest Vilas County and southeast Iron County, Wisconsin, with particular interest in an understanding of the potential for contamination of groundwater supply wells and the fate of wastewater that is infiltrated from treatment lagoons on the Reservation. This report describes the construction, calibration, and application of a regional groundwater flow model used to simulate the shallow groundwater flow system of the Reservation and water-quality results for groundwater and surface-water samples collected near a system of wastewater-treatment lagoons.

Groundwater flows through a permeable glacial aquifer that ranges in thickness from 60 to more than 200 feet (ft). Seepage and drainage lakes are common in the area and influence groundwater flow patterns on the Reservation. A twodimensional, steady-state analytic element groundwater flow model was constructed using the program GFLOW. The model was calibrated by matching target water levels and stream base flows through the use of the parameter-estimation program, PEST. Simulated results illustrate that groundwater flow within most of the Reservation is toward the Bear River and the chain of lakes that feed the Bear River. Results of analyses of groundwater and surface-water samples collected downgradient from the wastewater infiltration lagoons show elevated levels of ammonia and dissolved phosphorus. In addition, wastewater indicator chemicals detected in three downgradient wells and a small downgradient stream indicate that infiltrated wastewater is moving southwest of the lagoons toward Moss Lake.

Potential effects of extended wet and dry periods (within historical ranges) were evaluated by adjusting precipitation and groundwater recharge in the model and comparing the resulting simulated lake stage and water budgets to stages and water budgets from the calibrated model. Simulated lake water budgets and water level changes illustrate the importance of understanding the position of a lake within the hydrologic system (headwater or downstream), the type of lake (surfacewater drainage or seepage lake), and the role of groundwater in dampening the effects of large-scale changes in weather patterns on lake levels.

Areas contributing recharge to drinking-water supply wells on the Reservation were delineated using forward particle tracking from the water table to the well. Monte Carlo uncertainty analyses were used to produce maps showing the probability of groundwater capture for areas around each well nest. At the Main Pumphouse site near the Village of Lac du Flambeau, most of the area contributing recharge to the wells occurs downgradient from a large wetland between the wells and the wastewater infiltration lagoons. Nonetheless, a small potential for the wells to capture infiltrated wastewater is apparent when considering uncertainty in the model parameter values. At the West Pumphouse wells south of Flambeau Lake, most of the area contributing recharge is between the wells and Tippecanoe Lake.

The extent of infiltrated wastewater from two infiltration lagoons was tracked using the groundwater flow model and Monte Carlo uncertainty analyses. Wastewater infiltrated from the lagoons flows predominantly south toward Moss Lake as it integrates with the regional groundwater flow system. The wastewater-plume-extent simulations support the area-contributing-recharge simulations, indicating that there is a possibility, albeit at low probability, that some wastewater could be captured by water-supply wells. Comparison of simulated water-table contours indicate that the lagoons may mound the water table approximately $4 \mathrm{ft}$, with diminishing levels of mounding outward from the lagoons.

Four scenarios, representing potential alternatives for wastewater management, were simulated (at current discharge rates) to evaluate the potential extent of wastewater in the 
aquifer and discharge to surface-water bodies associated with each management scenario. Wastewater simulated to infiltrate through a hypothetical diffuser below a wetland south of the current lagoons appears to discharge to the overlying wetland and would likely discharge to Moss Lake as overland flow. Wastewater simulated to discharge to a small lake (Mindy Lake) between Moss and Fence Lakes appears to spread radially over a large area between the lakes. Wastewater simulated to discharge to lagoons south and northeast of the current lagoons also appears to spread radially, but the areas of the aquifer with the highest probability of encountering wastewater contamination would likely be between the lagoons and the nearest lake, where the wastewater would eventually discharge. Probability results for the wastewater-plume-extent scenarios are sensitive to the number of mathematical water particles used to represent infiltrating wastewater and the level of detail in the synthetic grid used for the probability analysis. Thus, probability results from wastewater-plume-extent simulations are qualitative only; however, it is expected that illustrations of relatively high or low probability will be useful as a general guide for decision making. Management problems requiring quantitative estimates of probability are best re-cast into problems evaluating the area that contributes recharge to the location of interest, which is not dependent upon the number of simulated particles or the resolution of a synthetic grid.

\section{Introduction}

An improved understanding of groundwater flow and groundwater/surface-water interaction on the Lac du Flambeau Reservation (Reservation), Wisconsin, is needed to plan for a reliable source of drinking water. The potential for contamination of groundwater supply wells and the fate of wastewater that infiltrates from wastewater-treatment lagoons on the Reservation is of particular interest. Of specific concern are the potential for the capture of wastewater by drinking-water supply wells and the potential for nutrient loading to Moss Lake from the wastewater-treatment lagoons. A study was conducted by the U.S. Geological Survey (USGS), in cooperation with the Lac du Flambeau Band of Lake Superior Chippewa (hereafter referred to as the Tribe) and the Indian Health Service, that focused on groundwater flow and interaction with surface water, delineation of the area contributing recharge to each of the drinking-water supply wells on the Reservation, and evaluation of the extent of wastewater infiltration from two lagoons into the groundwater flow system. The area contributing recharge to a well or lake is the two-dimensional projection, or footprint, on the land surface of the water entering the aquifer system that will be captured by a well or lake (Reilly and Pollock, 1993). Delineation of areas contributing recharge is useful for identifying the parts of the aquifer system that supply water to wells, which has utility for assessing a well's vulnerability to contamination.
A computer model was developed to simulate groundwater/surface-water interaction, areas contributing recharge to wells, and the flow of wastewater from wastewater-treatment infiltration lagoons to the groundwater flow system. Because the supply wells are open to a surficial aquifer that overlies confining units and groundwater/surface-water interaction is an inherently shallow phenomenon, the model was focused on the shallow groundwater system. New data were collected from wells and surface-water sites near the Village of Lac du Flambeau and the wastewater-treatment lagoons. Uncertainty associated with estimated parameter values and limited understanding of the connection between groundwater and wetlands near the lagoons were taken into account for mapping areas that contribute recharge to wells and for mapping wastewater plumes through the use of Monte Carlo uncertainty analyses that test a broad range of parameter combinations. Geologic and hydrologic data used during the study consisted of interpretive maps, previously published reports, and historical and contemporary streamflow and water-table measurements.

\section{Purpose and Scope}

The purpose of this report is to describe shallow groundwater flow and interaction with surface-water bodies on the Reservation; the water-quality conditions of groundwater and surface water near a system of wastewater-treatment lagoons; the construction and calibration of a regional groundwater flow model; the application of the model to evaluate the response of selected lakes on the Reservation to prolonged wet and dry periods; and the application of the model to simulate areas contributing recharge to wells and the extent of infiltrated wastewater in the shallow groundwater flow system, including the calculation of the uncertainty associated with these results. Simulations were performed using assumptions of steady-state conditions, in which no seasonal or long-term changes in water levels, recharge, or pumping are considered. Results of the two-dimensional areal groundwaterflow model used to simulate the system, which incorporated limited hydrogeologic heterogeneity of model properties, are presented. The purpose of the model is to simulate regional groundwater/surface-water interaction, delineate areas contributing recharge to pumped wells, and estimate the extent of wastewater infiltration from treatment lagoons. Areas contributing recharge to the wells were delineated for two pumping scenarios: a baseline using current pumping rates and a future pumping rate scenario representative of expected water demand by the year 2035 .

\section{Physical Setting}

The study area is located in southwest Vilas County and southeast Iron County, Wis., and encompasses the headwater area of the Bear River Watershed (fig. 1). Seepage and drainage lakes are common in the area and affect the groundwater 


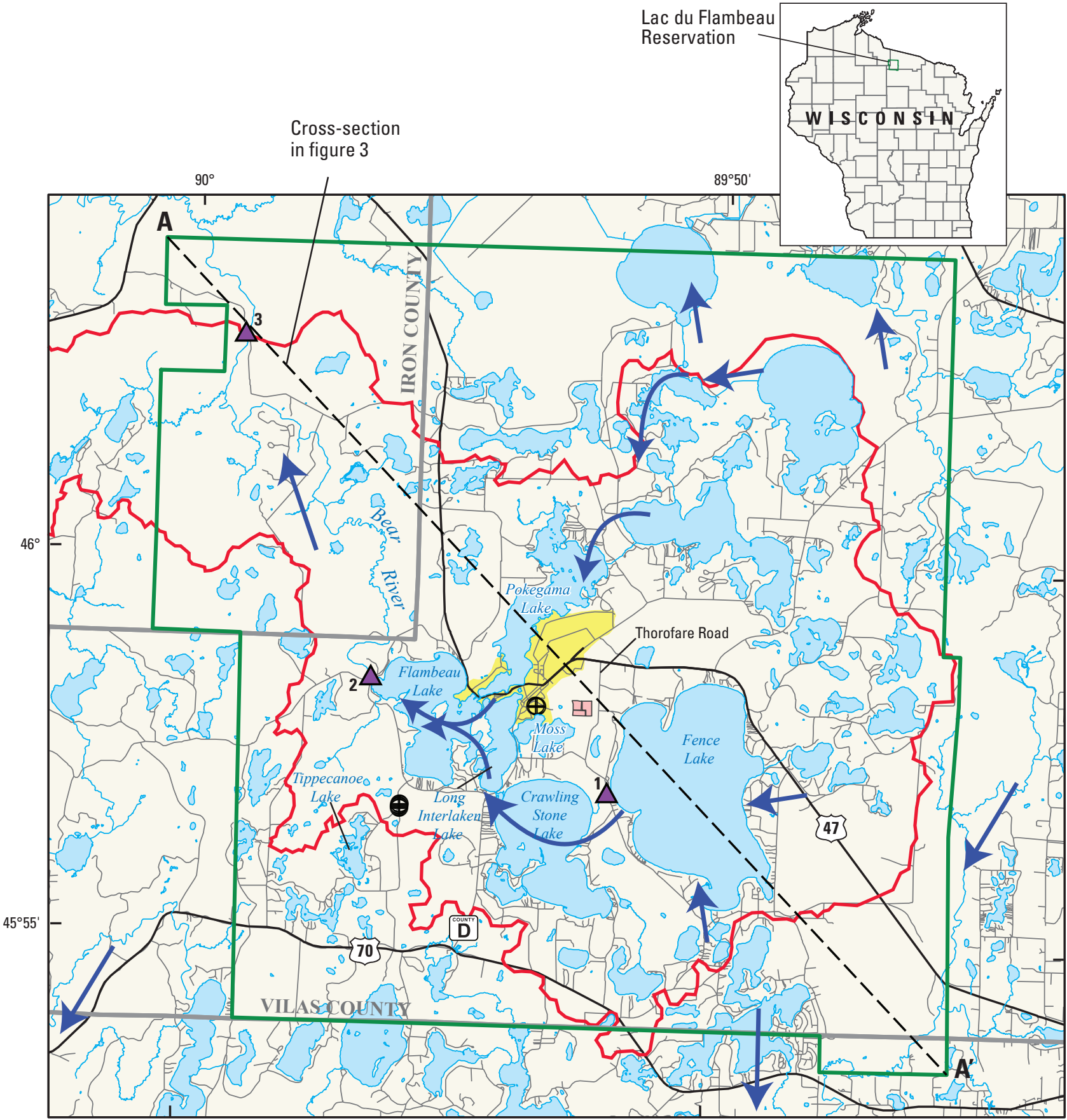

Base map from U.S. Census Bureau, 2013 and Wisconsin Department of Natural Resources, 2009
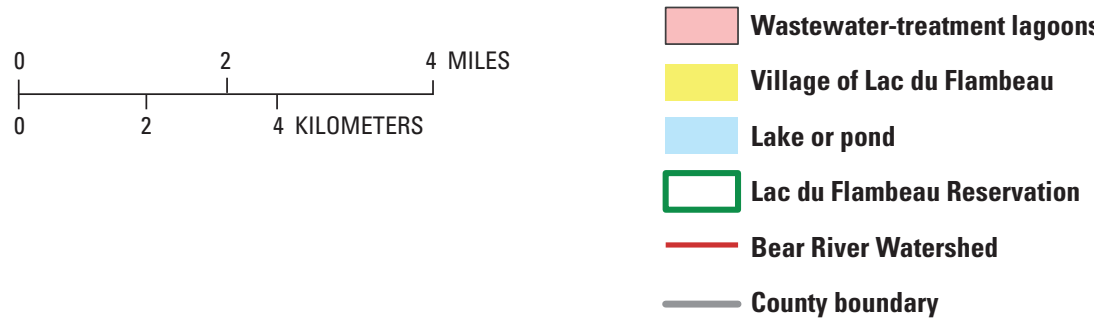

EXPLANATION

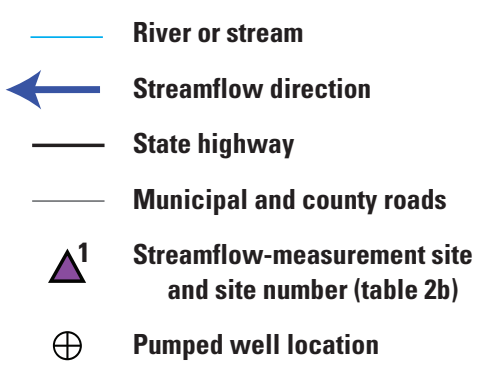

Figure 1. Location of the Lac du Flambeau Reservation and streamflow-measurement sites, in Iron and Vilas Counties, Wisconsin. 
flow system. Seepage lakes do not have any surface-water outlet and can be either perched above the water table or well connected to the regional groundwater flow system. In comparison, drainage lakes are identified by the presence of a surface-water outlet that flows from the lake. Drainage lake water levels tend to fluctuate less than seepage lake water levels because the amount of water leaving a drainage lake through the outlet stream increases or decreases as the water level increases or decreases. The prominence of large drainage lakes on the Reservation was expected to exhibit a strong control on groundwater levels and flow patterns on the Reservation. Previously published water-table contours by Batten and Lidwin (1996) show that most lakes on the Reservation appear to be well connected with the groundwater flow system. Another hydrologically important feature is a system of wastewater-treatment lagoons. Infiltrated water from these lagoons is expected to integrate into the regional groundwater flow system, which will transport nutrients and other chemicals down-gradient toward lakes, streams, or wells on the Reservation.

\section{Data Sources}

Geologic data used in this study consist of interpretive maps by Attig (1985), lithologic data provided by the Indian Health Service (2009) and Batten and Lidwin (1996), and lithologic samples collected as part of this project. These data were used to estimate the distribution and properties of glacial sedimentary deposits.

With the few exceptions noted below, surface-water elevations used for model development and calibration were derived from water levels reported on USGS topographic maps and are expected to represent long-term average conditions to within a few feet. Surface-water elevations for Fence, Crawling Stone, Moss, Pokegama, Long Interlaken, and Flambeau Lakes were derived from a field survey conducted on July 29, 2010, which produced lake water elevations accurate to within $0.5 \mathrm{ft}$ or better. All surface-water-level measurements are reported as feet and are referenced to the North American Vertical Datum of 1988 (NAVD 88). Streamflow data were obtained from the USGS National Water Information System (NWIS) database (Dempster, 1990) and measurements made during this study. Groundwater-level data were obtained from Batten and Lidwin (1996), well construction reports submitted to the Wisconsin Department of Natural Resources (2010), and measurements made during this study.

\section{Water-Quality Methods and Results of Analysis of Groundwater and Surface Water near the Wastewater-Treatment Lagoons}

Water-quality samples were collected from monitoring wells, a stream, a wastewater infiltration lagoon (fig. 2), and blank water (station number 430533089155500) using standard USGS protocol (U.S. Geological Survey, variously dated). All samples were analyzed for dissolved oxygen, $\mathrm{pH}$, specific conductance, temperature, and nutrients (total nitrogen, ammonia, nitrate and nitrite, and dissolved phosphorus). Results of analyses of groundwater and surface-water samples collected near the lagoons show that concentrations of ammonia and dissolved phosphorus were elevated downgradient from the infiltration lagoons compared with concentrations in groundwater from a well upgradient from the lagoons that was installed to sample background concentrations of water-quality constituents (Appendix).

A suite of wastewater indicator chemicals (69 chemicals plus 4 surrogates for quality control) was analyzed for a subset of the wells and surface-water sites (Appendix), including four "environmental" sites (wells 455758089524301 and 455801089524301, a temporary minipiezometer in the Moss Lake wetland, and a small tributary stream to Moss Lake downgradient from the lagoons), an infiltration lagoon, and a reference or "blank" sample from water used to rinse sampling equipment between wells. Samples from the four "environmental" sites represent water from the natural environment in the area of concern, as opposed to samples collected from the lagoon or those collected for quality-control purposes. Results of analyses of samples from the four "environmental" sites show that most constituents (45 of 69 chemicals tested) had concentrations at or below detection limits or levels found in blank water. However, at least one of the wastewater indicator chemicals had a concentration in excess of that in blank water for each of the four "environmental" sampling sites. Of the 24 wastewater indicator chemicals detected, the most common (detected in all four "environmental" samples with concentrations greater than that in the blank water) were DEET and isophorone. DEET is used as an insect repellent and has been found in natural waters (Kolpin and others, 2002), originating from its production and use. DEET is known to be easily introduced to samples during sample collection; however, concentrations in blank water were lower than those in the environmental samples, indicating that contamination was not a substantial contributor to measured concentrations for this study. Isophorone is used as a solvent in some inks, paints, adhesives, and pesticides, but has been found to occur naturally in cranberries (California Office of Environmental Health Hazard Assessment, 2001). 


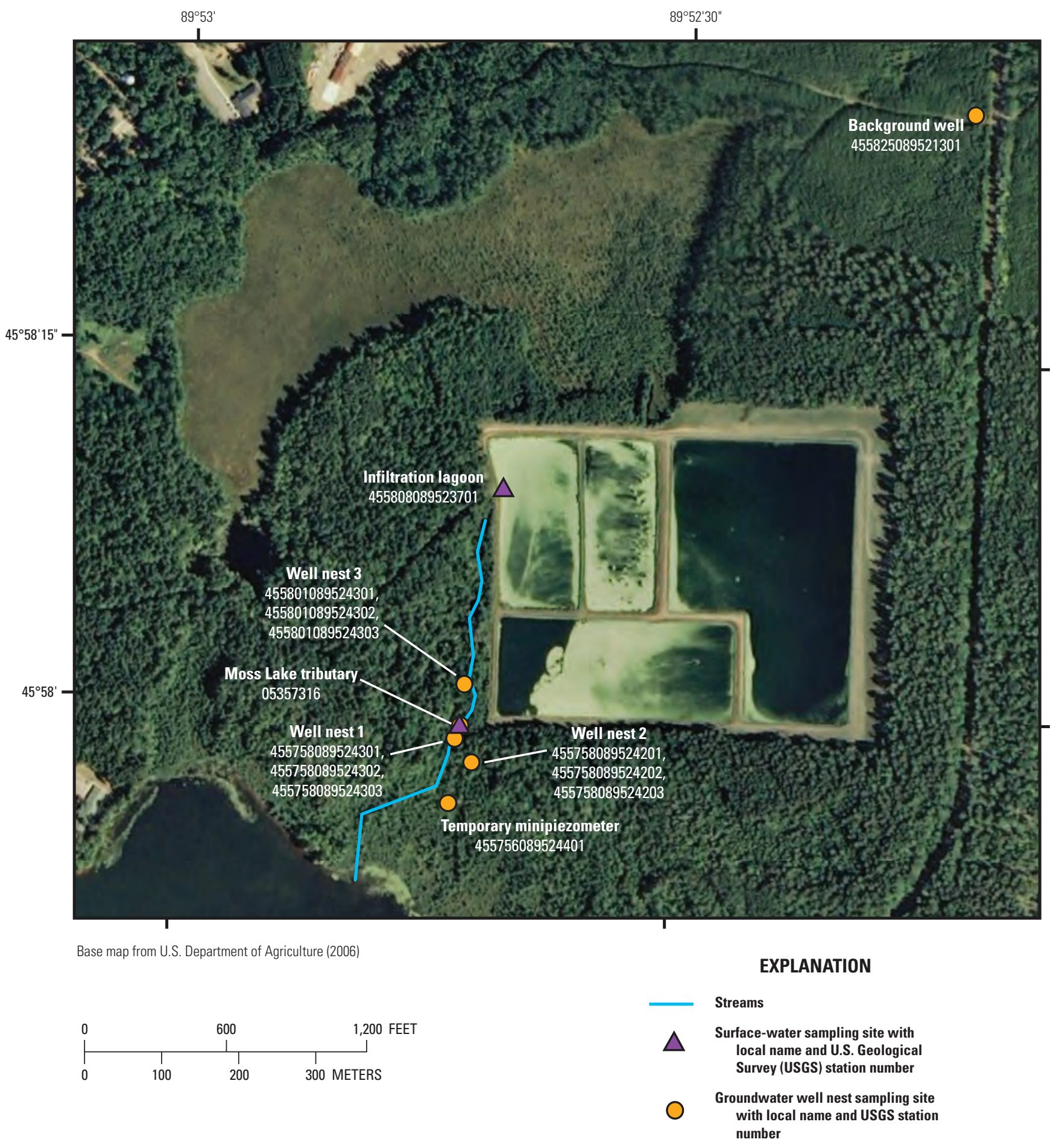

Figure 2. Location of wastewater-treatment lagoons, well nest sampling sites, and surface-water sampling sites, Lac du Flambeau Reservation, Wisconsin. 
The highest concentrations relative to the detection limit or blank-water concentrations were for the chemicals camphor and p-Cresol (24 and 22 times the detection limit, respectively) in the tributary stream sample. Camphor is commonly used as a topical pain reliever and cough suppressant in some topical cough treatments (for example: http://www.vicks.com/ products/vapo-family/vaporub-topical-ointment/), and as a plasticizer, a moth repellent, and antimicrobial substance. Cresols are commonly used as disinfectants and wood preservatives, and in the formulation of deodorizers (U.S. Environmental Protection Agency, 2007). The detections of wastewater tracers in this relatively pristine setting indicate that infiltrated wastewater is moving to the southwest of the lagoons toward Moss Lake.

\section{Development of the Two-Dimensional Model}

The two-dimensional model used for this study was developed using the analytic element groundwater flow modeling code, GFLOW (Haitjema, 1995). Hunt (2006) gives a review of applications of the analytic element method, and Haitjema (1995) discusses the underlying concepts and mathematics of the method in detail. A complete description of analytic elements is beyond the scope of this report, but a brief description follows.

An infinite aquifer is assumed in analytic element modeling. The model area does not require a grid or involve interpolation between cells (as are required for finite difference or finite element methods). To construct an analytic element model, the modeler enters features important for controlling groundwater flow (for example, wells and surface-water features) as mathematical elements or strings of elements. The amount of detail specified for the features depends on distance from the area of interest and the purpose of the model. Each element is represented by an analytic solution to the groundwater flow equation. The effects of these individual solutions are added together to form a solution for any location in the simulated groundwater-flow system. Because the solution is not confined to a grid, heads and flows can be computed anywhere in the model domain without interpolating between grid cells. In the GFLOW model used here, the analytic elements are two dimensional and are used only to simulate steady-state conditions, that is, water levels that do not vary with time. The analytic element method and comparisons of analytic element to finite-difference numerical modeling techniques have been discussed by others (Haitjema, 1995; Hunt and others 1998; and Hunt and others, 2003).

In this study, the GFLOW model was coupled with the parameter estimation code PEST (Doherty, 2011), for calibration by means of the Gauss-Levenberg-Marquardt parameterestimation technique. Numerous publications detail the advantages of such formal parameter estimation (for example, Poeter and Hill, 1997; Kelson and others, 2002). The primary benefit of a properly prepared and executed parameter-estimation calibration over typical trial-and-error calibration is the ability to algorithmically calculate parameter values (for example, hydraulic conductivity and recharge) that are a quantified best fit between simulated model output and target data (for example, groundwater levels and stream base flows). In addition, parameter sensitivity can be quantified and assessed.

\section{Development of the Conceptual Model}

Before simulating the groundwater system using a flowmodeling code, a conceptualization of the hydrologic system is essential because it forms the framework for model development and reduces the groundwater system into important component parts. This reduction is a necessary simplification of the hydrologic system because inclusion of all of its complexities into a model is not feasible. Steps in the development of the conceptual model include (1) characterization of the aquifer(s), (2) identification of sources and sinks of water, and (3) identification and delineation of hydrologic boundaries in the area of interest. The conceptual model of the hydrologic system is shown in figure 3 . 


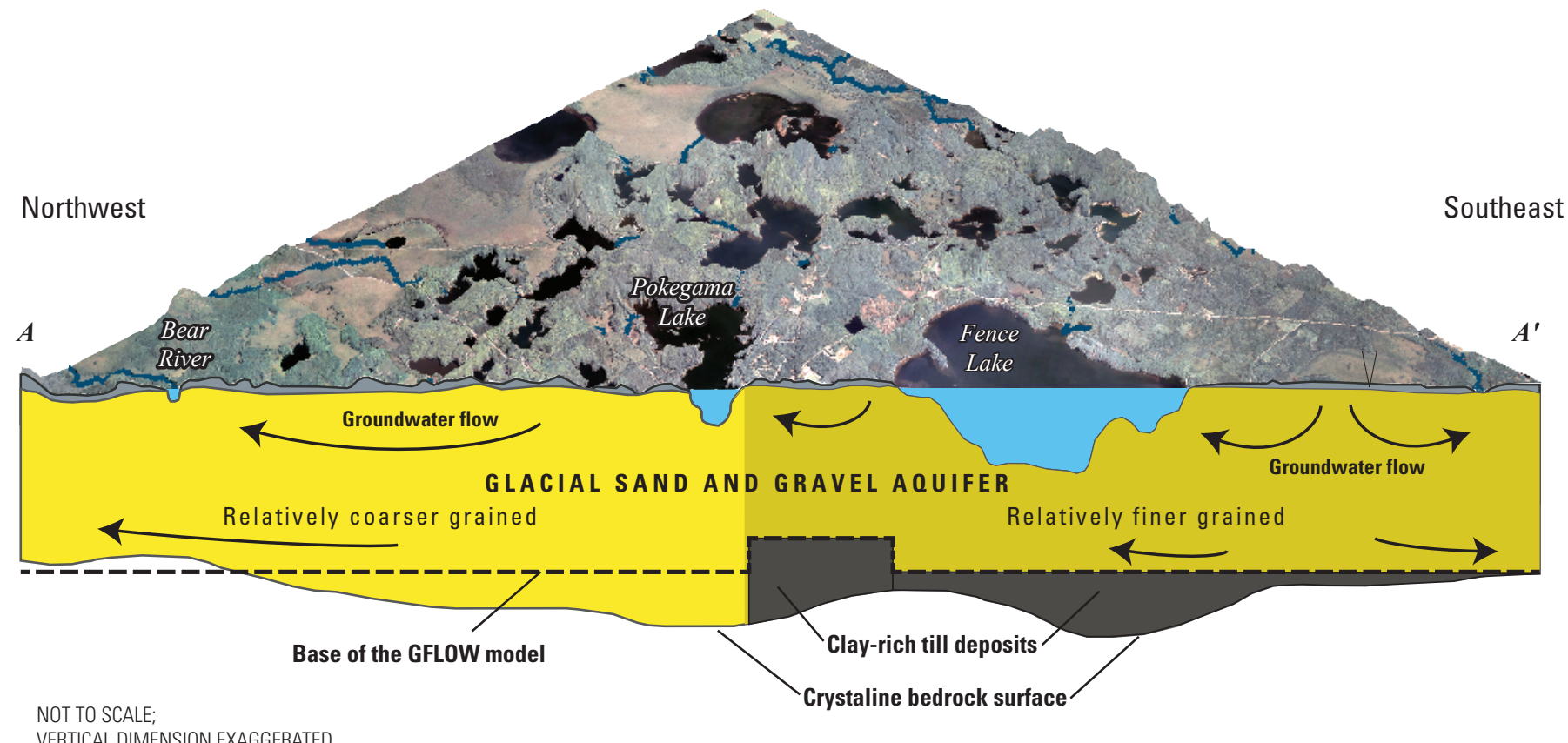

Figure 3. Cross section $A-A^{\prime}$ of the conceptual model of groundwater flow, Lac du Flambeau Reservation, Wisconsin.

The regional groundwater system on the Reservation is a relatively thin (ranging from about 50 to $250 \mathrm{ft}$ in thickness) glacial aquifer overlying comparatively impermeable Precambrian igneous and metamorphic rocks (Attig, 1985). The glacial aquifer is dominated by sand and gravel deposits, but includes areas of relatively coarser or finer material, as well as layers of clay-rich till. An area of relatively finergrained material in the eastern portion of the Reservation was identified from lithologic descriptions of wells by Batten and Lidwin (1996), and conceptualized to have relatively lower hydraulic conductivity than areas to the west. Similarly, a relatively continuous layer of clay-rich till has been mapped by Attig (1985) in the eastern portion of the Reservation, which is conceptualized to represent the base of the upper-most sand and gravel aquifer in the Reservation (fig. 3).

Groundwater moves from higher to lower hydraulic potential (areas of higher groundwater levels to areas of lower groundwater levels) and generally flows toward the Bear River and lakes that drain into it. Groundwater generally enters the groundwater system throughout the reservation, except where it discharges to surface water bodies. Groundwater discharges to surface-water features such as streams and lakes, or to pumped wells. Accurate locations of surface-water features and pumped wells are, therefore, critical to simulating the groundwater system within the Reservation. 


\section{Description of the GFLOW model}

Initial model development included estimating the elevation of the base of the groundwater system, the horizontal hydraulic conductivity, and the recharge rate. The base of the model (1,500 ft above NAVD 88 ) roughly corresponds with the top of the crystalline bedrock in the western half of the Reservation and the top of a relatively thick layer of clay-rich till in the eastern half of the Reservation. This clay-rich till layer is identified in cross sections by Attig (1985) and noted in numerous lithologic descriptions for wells described by Batten and Lidwin (1996). Because the primary goal of the model was to simulate the shallow groundwater flow system and supply wells for the village of Lac du Flambeau are screened above clay that was identified in exploratory drilling (Indian Health Service, 2009), this clay-rich till was assumed to represent the base of the shallow groundwater flow system in the eastern half of the Reservation (fig 4). In addition, several feet of clay were collected via soil cores near the Village of Lac du Flambeau during this study; the top of the clay started near $1,535 \mathrm{ft}$ above NAVD 88 . The model base was raised from $1,500 \mathrm{ft}$ to $1,535 \mathrm{ft}$ above NAVD88 in a local area surrounding the core samples in order to better represent the local transmissivity (aquifer hydraulic conductivity times saturated thickness). The extent of the shallow clay is unknown, but was represented in the GFLOW model based on lithologic descriptions for wells by Batten and Lidwin (1996), cores collected for this study, and the general shape of adjacent surface-water bodies.

In two-dimensional areal models, where transmissivity of a single layer represents the flow system, the base elevation is correlated with hydraulic conductivity. Therefore, parameter calibration focused on horizontal hydraulic conductivity rather than the aquifer base elevation. In addition to horizontal hydraulic conductivity, groundwater recharge was considered a calibration parameter; both properties were varied during model calibration. Initially, one recharge value and one horizontal hydraulic conductivity zone were used to represent the entire model domain. During calibration of the model, however, it was determined that the shallow groundwater system is better represented by one recharge value and two hydraulicconductivity zones that represent the variability of hydraulic properties of the glacial sediments.

Surface-water features, such as streams and lakes, were simulated with various analytic elements in the model. Streams outside the Reservation and the Bear River watershed (fig. 1) were simulated as "far field" linesinks for which the stream stage is fixed and there is no resistance between the groundwater and surface-water systems. The location and elevation of far-field surface-water features were added to the model to control the water levels at the model boundary and to have the model explicitly simulate groundwater divides surrounding the Reservation and Bear River watershed (the "near field" area of interest). The far-field elements are generally beyond the extent of the Reservation shown in figure 4.
The Bear River and small lakes that are part of the river system were simulated as routed near-field elements, or stream linesinks. These near-field linesinks have a finer discretization than far-field linesinks, and base flow in the streams is computed by the model as a function of the groundwater level at the stream and the ratio of stream-sediment thickness to permeability, known as resistance. Base flow is the portion of streamflow produced by groundwater discharge to surface waters, and excludes overland runoff. Use of routed near-field stream elements allowed the model to route base flow along the river and through lakes so that simulated base flows could be compared with target base flows during model calibration. Streambed resistance in the near field was set equal to 0.5 day for rivers. Resistance is defined as the streambed thickness divided by the vertical hydraulic conductivity of the sediment. For example, a 1-ft stream bed thickness with a vertical hydraulic conductivity of 2 feet per day ( $\mathrm{ft} / \mathrm{d})$ would result in a resistance of 0.5 day. Neither stream bed thickness nor vertical hydraulic conductivity are well-defined by field measurements; however, parameter sensitivity assessments demonstrated that the model results were not sensitive to changes in streambed or lakebed resistance when varied over reasonable ranges. Therefore, resistance values for all streams were fixed at 0.5 day in all calibration runs. The value of lake linesink resistance was set to 10 days for seepage lakes and 1 day for drainage lakes, reflecting the expectation that fine-grained sediments are trapped in seepage lakes, which lack a stream outlet that may remove some fine-grained sediment from drainage lakes. The width assigned to linesinks representing lakes was approximately the length of the shortest axis of the lake represented by the linesink (Haitjema, 2005). The width of each stream was assigned according to stream order and field observations and ranged from 10 to $100 \mathrm{ft}$.

Near-field lakes were simulated as (1) high-permeability seepage lakes (no inlet or outlet stream), (2) routed stream linesinks along the perimeter of the lake with high-permeability areas inside the lake to simulate drainage lakes with limited information on base flow through inlet and outlet streams, and (3) lake water-budget linesinks (lake elements) for which the lake stage is computed by the model on the basis of a simulated water budget (fig 4). While the areal extent of linesinks representing lakes is fixed in the model, lake elements incorporate a stage-to-area table that represents the lake bathymetry and improves simulation of changes in the lake stage and associated volume. Drainage lakes for which outlet streamflows were measured during a reconnaissance survey on July 29, 2010, and two seepage lakes expected to be important for affecting groundwater flow directions in areas of interest were simulated with lake elements. Because of nearly identical water levels, Crawling Stone, Flambeau, Long Interlaken, Moss, and Pokegama Lakes were simulated with a single lake element. Fence Lake, Tippecanoe Lake, and Mindy Lake (a small seepage lake between Fence and Moss Lakes) also were simulated with lake elements. Within the perimeter of each lake, the recharge rate applied to the lake represented net 


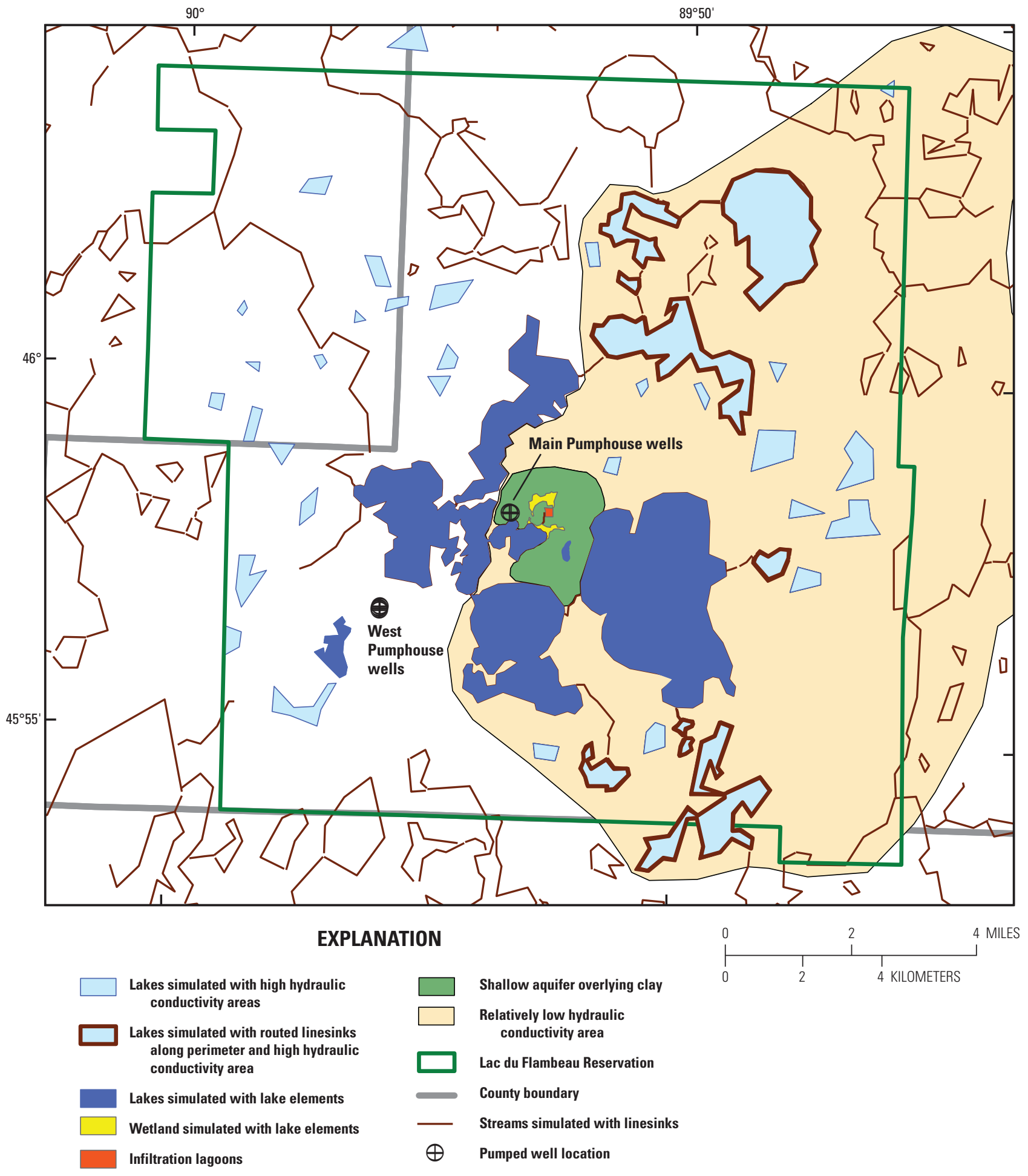

Figure 4. Hydrologic features simulated with analytic elements, Lac du Flambeau Reservation, Wisconsin. 
precipitation rather than groundwater recharge; therefore, the water added to the lakes differs from that of the regional aquifer $\left(\mathrm{R}_{\text {lake }}=\mathrm{P}-\mathrm{E}_{\text {lake }}\right.$, where $\mathrm{R}_{\text {lake }}$ is the net precipitation recharged inside the lake, $\mathrm{P}$ is the annual precipitation, and $\mathrm{E}_{\text {lake }}$ is the evaporation rate from the lake). The net precipitation recharged inside all near-field lakes in the model was set equal to 5.9 inches per year (in/yr). This value was determined by comparing long-term precipitation (31.9 in/yr) at the National Weather Service Cooperative Observer Program (COOP) station at Minocqua (station 475516) with estimated long-term average lake evaporation $(26.0 \mathrm{in} / \mathrm{yr})$ for the area that is based on computed evaporation from Sparkling Lake (Lenters and others, 2005).

Of particular interest for this study was understanding groundwater flow patterns near a system of wastewatertreatment lagoons east of the village of Lac du Flambeau. Initial model simulations indicated that simulated groundwater flow patterns in this area may be sensitive to wetlands that appeared, on the basis of surveyed water levels on July 29, 2010 , to be well connected with the water table. No additional hydrologic information on the wetlands was available. Therefore, to ensure proper flexibility within the model, two wetlands near the wastewater lagoons were simulated using lake elements. In this manner, the model computed the water level in the wetlands on the basis of simulated groundwater levels and a resistance value for the wetlands that was estimated during the calibration process. The same approach for net precipitation (5.9 in/yr) and width was applied to the wetlands using lake elements.

Groundwater withdrawal from the aquifer was simulated by adding pumped high-capacity wells to the model (fig 4). The only pumped high-capacity wells in the near-field area were production wells that serve the Reservation. Information on the location, depth, and withdrawal rates were supplied by the Indian Health Service (2009). Pumping of private residential wells was not simulated in the model because withdrawal rates tend to be low and much of the withdrawal is returned to the aquifer through septic-system infiltration.

\section{Model Calibration}

Groundwater flow patterns are affected by the pattern of surface-water features such as rivers and lakes that intersect the water table, the aquifer transmissivity (thickness and hydraulic conductivity), recharge to the aquifer, and pumping. Initial hydraulic conductivity and recharge values were estimated from prior studies in the area (Robertson and others, 2012; Pint and others, 2003). Final values (table 1) were computed through the model calibration process during which values were adjusted to match the weighted, squared differences between simulated and target values of groundwater levels and stream base flows. Fitting simulation results to these target values was done by a computer-assisted calibration process using PEST (Doherty, 2011).

Groundwater-level targets consisted of both historical and contemporaneous (2010) measurements (table 2A). Historical groundwater levels included data from 15 monitoring wells and 8 private wells described by Batten and Lidwin (1996) and 57 private wells with reported latitude and longitude coordinates within the Reservation that were obtained from the Wisconsin Department of Natural Resources (WDNR, 2010). Contemporary (2010) water levels were measured in existing wells around the wastewater-treatment lagoons and in new wells installed near the lagoons as part of this study (seven wells total) (table 2A). In addition, an average water level of 1,568 ft, provided by the Tribe (Kristen Hansen, Lac du Flambeau Tribe, written communication, February 1, 2011), for monitoring wells near the intersection of County Highway D and State Highway 70 was used as a target. Contemporary water levels were given higher weight (2) for calibration than historical water levels $(0.2$ to 1 ; table $2 A)$ because of an expected higher level of accuracy and because

Table 1. Calibrated parameter values and composite sensitivities for the analytic element model of the Lac du Flambeau Reservation, Wisconsin.

[in/yr, inches per year; $\mathrm{ft} / \mathrm{d}$, feet per day; $\mathrm{ft} /(\mathrm{ft} / \mathrm{d})$, feet divided by feet per day]

\begin{tabular}{|c|c|c|c|}
\hline Parameter name & $\begin{array}{c}\text { Calibrated } \\
\text { parameter value }\end{array}$ & Sensitivitiy & Description \\
\hline R-reservation & $9.2 \mathrm{in} / \mathrm{yr}$ & 0.37 & Uniform recharge to the entire model area. \\
\hline K-west_reservation & $47 \mathrm{ft} / \mathrm{d}$ & 0.34 & $\begin{array}{l}\text { Hydraulic conductivity of the western portion of the model area representing } \\
\text { glacial deposits above crystaline bedrock. }\end{array}$ \\
\hline K-east_reservation & $21 \mathrm{ft} / \mathrm{d}$ & 1.3 & $\begin{array}{l}\text { Hydraulic conductivity of the eastern portion of the model area representing } \\
\text { glacial deposits above a clay-rich deposit identified by Attig (1985). }\end{array}$ \\
\hline C-wetlands & 24 days & 0.06 & $\begin{array}{l}\text { Resistance to groundwater/surface-water interaction (sediment thickness/hy- } \\
\text { draulic conductivity of sediments, in units of } \mathrm{ft} /(\mathrm{ft} / \mathrm{d} \text { ) or the equivalent units of } \\
\text { days) for wetlands simulated with lake elements. }\end{array}$ \\
\hline
\end{tabular}


Table 2A. Calibration results for groundwater and lake level targets and associated weights used for calibration with the parameterestimation program PEST, Lac du Flambeau Reservation, Wisconsin.

[ME, mean error; MAD, Mean Absolute Difference; RMSD, Root-Mean-Square Difference; std, Standard Deviation; CI, Confidence Interval]

\begin{tabular}{|c|c|c|c|c|c|c|}
\hline Target type & $\begin{array}{l}\text { Number of } \\
\text { targets }\end{array}$ & $\begin{array}{c}\text { ME } \\
\text { (feet) }\end{array}$ & $\begin{array}{l}\text { MAD } \\
\text { (feet) }\end{array}$ & $\begin{array}{l}\text { RMSD } \\
\text { (feet) }\end{array}$ & $\begin{array}{l}\text { Weight } \\
\text { (1/std) }\end{array}$ & $\begin{array}{l}\text { Equivalent standard } \\
\text { deviation-calculated } \\
95 \% \mathrm{Cl} \\
\text { (feet) }\end{array}$ \\
\hline $\begin{array}{l}\text { Historical static water level from private drinking } \\
\text { wells reported by Batten and Lidwin (1996) }\end{array}$ & 8 & -3.7 & 7.3 & 8.4 & 0.4 & 5 \\
\hline $\begin{array}{l}\text { Measured water level in water-table monitoring } \\
\text { wells near the Lagoons }\end{array}$ & 7 & -0.3 & 1.7 & 1.9 & 2 & 1 \\
\hline $\begin{array}{l}\text { Average measured water level of monitoring wells } \\
\text { at a contamination site near County Highway D } \\
\text { and State Highway } 70\end{array}$ & 1 & -6.5 & 6.5 & 6.5 & 2 & 1 \\
\hline $\begin{array}{l}\text { Lake and wetland water levels measured on July } \\
\qquad 29,2010\end{array}$ & 5 & 2.3 & 2.3 & 2.9 & $1-2$ & $1-2$ \\
\hline $\begin{array}{l}\text { Water level difference between the background } \\
\text { well and the shallow well at nest } 1 \text { (well 1A) } \\
\text { near the lagoon (fig. 4) }\end{array}$ & 1 & 0.6 & 0.6 & 0.6 & 8 & 0.25 \\
\hline
\end{tabular}

model simulations focused on conditions in the recent past. In addition, water levels for seepage lakes and wetlands that were expected to be in close communication with the groundwater system were also used as water level targets. Target water levels obtained from topographic maps (32 targets) were assigned relatively less weight (0.2) compared to weights (1-2) for water levels that were measured directly on July 29, 2010 (5 targets). Lastly, a high weight (8) was given to a target representing the difference between a measured water level at an upgradient "background" monitoring well and a shallow downgradient monitoring well near the wastewater lagoons (Well nest 1; fig. 2). The high weight for this water level difference target is related to the importance of simulating the proper flow gradient near the lagoons for evaluating migration of infiltrated wastewater in the aquifer. The last column in table $2 A$ describes how the assigned weights relate to expected measurement error and uncharacterized water level fluctuations through the calculation of an equivalent standard deviation using a 95 percent confidence error. For example, water level targets with a weight of 2 are expected to correspond to a 1-ft standard deviation (relatively small variability), whereas a weight of 0.2 corresponds to a $10-\mathrm{ft}$ standard deviation (relatively large variability).

Contemporary base flows also were used to calibrate the model (table $2 B$ ). Base flow targets included a long-term gaging station on the Bear River (fig. 1) near Manitowish (site 3, located along East River Road), and two streamflow measurements collected for the study on July 29, 2010 (the outlets of Fence (site 1) and Flambeau (site 2) Lakes). The streamflow measurements on July 29, 2010, followed two weeks with less than 1.7 inches of precipitation and occurred during a two-week period for which Lenters and others (2005) estimated the highest evaporation rate of the summer. Thus, it was assumed that modest rainfall events produced relatively little overland runoff due to dry conditions and low soil-moisture content during the period immediately prior to the flow measurements. Moreover, for the purpose of calibrating the model, the one-time streamflow measurements were adjusted to the long-term average base flow at the Bear River gaging station. Long-term average base flow at the Bear River gaging station was assumed to correspond to the 50 percent flow duration (Q50), or the amount of streamflow that is exceeded 50 percent of the time, for water years 1991 to 2010. The Q50 of 49.8 cubic feet per second $\left(\mathrm{ft}^{3} / \mathrm{s}\right)$ for the Bear River gaging station was about 60 percent of the mean daily flow $\left(81 \mathrm{ft}^{3} / \mathrm{s}\right)$ recorded on July 29, 2010. Thus, all measured streamflows from July 29, 2010, were reduced to approximately 60 percent their original value to better match long-term average conditions in the Bear River watershed. The target flow for the outlet of Flambeau Lake was reduced an additional 7 percent on the basis of the "fair" suitability of the site for discharge measurement (Ryan Jirik, U.S. Geological Survey, written commun., July 15, 2011) in order to ensure an increase in base flow in the downstream direction for the flow targets. 
Table 2B. Calibration results for stream base-flow targets and associated weights used for calibration with the parameter estimation program PEST, Lac du Flambeau Reservation, Wisconsin.

[fts $/ \mathrm{s}$, cubic feet per second; CI, Confidence Interval]

\begin{tabular}{clcccccc}
\hline $\begin{array}{c}\text { Site } \\
\text { number } \\
\text { in } \\
\text { figure 1 }\end{array}$ & Stream name & $\begin{array}{c}\text { Target } \\
\text { base flow } \\
\left(\mathbf{f t t}^{3} / \mathbf{s}\right)\end{array}$ & $\begin{array}{c}\text { Simulated } \\
\text { base flow } \\
\left(\mathbf{f t}^{3} / \mathbf{s}\right)\end{array}$ & $\begin{array}{c}\text { Difference } \\
\left(\mathbf{f t}^{3} / \mathbf{s}\right)\end{array}$ & $\begin{array}{c}\text { Difference } \\
\text { (percent) }\end{array}$ & Weight & $\begin{array}{c}\text { Equivalent coefficient of } \\
\text { variation-calculated } \\
\mathbf{9 0 \%} \mathbf{~ C l} \\
(\mathbf{p e r c e n t}\end{array}$ \\
\hline 1 & Fence Lake outlet & 14.6 & 9.9 & 4.7 & 32 & $1.3 \mathrm{E}-05$ & 10 \\
2 & Flambeau Lake outlet & 48.3 & 32.2 & 16.1 & 33 & $4.0 \mathrm{E}-06$ & 10 \\
3 & Bear River at East River Road & 49.8 & 49.8 & 0.0 & 0 & $1.9 \mathrm{E}-05$ & 2 \\
\hline
\end{tabular}

During the calibration, model values of hydraulic conductivity, groundwater recharge, and wetland sediment resistance were adjusted by the parameter estimation code PEST (Doherty, 2011) to improve the match between stimulated and target water levels and base flows. Hydraulic conductivity was separated into two zones for calibration of the model, with one zone being an area of relatively low hydraulic conductivity shown on figure 4 , and the other zone being the rest of the model domain. Geologic properties at wells in the eastern half of the Reservation appear to include a larger amount of silt and clay than at the wells drilled in the western half of the Reservation, as summarized in tables by Batten and Lidwin (1996). The regional model calibration was consistent with these data; the calibration was improved by simulating lower hydraulic conductivity $(21 \mathrm{ft} / \mathrm{d})$ in the eastern half of the Reservation than in the western half of the Reservation $(47 \mathrm{ft} / \mathrm{d})$ (table 1). A shallow layer of clay was identified from lithologic samples collected for this project near the wastewater-treatment lagoons and from reported lithologies for the Main Pumphouse wells (Indian Health Service, 2009). This shallow clay layer was interpreted to isolate a lower aquifer system from an upper aquifer system, the latter of which is the source of water for the Main Pumphouse wells and is the aquifer system that interacts with the infiltration lagoons and nearby lakes. This upper aquifer system was simulated in the model by elevating the bottom of the model for a generalized area (the true extent of which was uncertain because of limited data for the area) around the Main Pumphouse wells and lagoons, such that the base of the model in this area corresponds with the top of the clay layer at $1,535 \mathrm{ft}$ (fig. 4). A uniform recharge rate of $9.2 \mathrm{in} / \mathrm{yr}$ was calibrated for the entire model domain, and a resistance of 24 days was calibrated for wetlands simulated as lake elements near the wastewater-treatment lagoons (table 1).
Following calibration, model-simulated groundwater level and stream base flow show a close fit to target values. Unweighted statistics relating all target water levels to all simulated levels included a mean difference of $-3.8 \mathrm{ft}$ (negative indicates that target values are, on average, less than simulated values), a mean absolute difference of $6.4 \mathrm{ft}$, and a root mean squared difference of $8.4 \mathrm{ft}$. Groups of highly weighted targets had smaller residuals than target groups given lower weight (table $2 A$ ). Simulated water levels generally matched target water levels over the entire 70-ft range (fig. 5) with little spatial bias (fig. 6). Simulated stream base flow values were within 35 percent of estimated base flows at all three target locations (table $2 B$ and fig. 6 ), with base flow at the main integrator of flow within the Reservation, the Bear River gaging station, simulated within 1 percent of the target flow.

\section{Sensitivity and Uncertainty Analysis}

Uncertainty is always present in environmental simulations because a model is an imperfect simulator of the natural world. However, the importance of each model input parameter for the calibration can be evaluated through sensitivity tests in which the value of a parameter, such as hydraulic conductivity, is adjusted above or below the calibrated value and the magnitude of changes in simulated groundwater levels and base flows are quantified. In this study, PEST was used to calculate the sensitivity of all water-level and base-flow targets to changes in each parameter value during the calibration process (table 1). For the final calibrated parameter values, composite sensitivities computed by PEST indicate that water levels and base flows were most sensitive to the recharge rate and hydraulic conductivity values, and less sensitive to sediment resistance values. Initial sensitivity analyses showed similar results and were used to guide the selection of parameters for estimation. 
Although sensitivities are useful for identifying parameters that are important for matching calibration targets, it is not always the case that predictions, such as the area that contributes recharge to wells, will be sensitive to these same calibration parameters. That is, the area contributing recharge may be sensitive to parameters, such as the sediment resistance for wetlands, that were identified as being of low sensitivity to water-level and base-flow targets during the calibration process. To address this potential confounding factor, a Monte Carlo technique was employed for scenario testing in this report. Parameter covariance matrices computed by PEST during the calibration process were used to guide the range around the calibrated values that were tested for all four calibrated parameters. That is, about one thousand realizations were generated for each scenario by randomly selecting a unique set of parameter values on the basis of the parameter covariance matrices. This resulted in a set of about one thousand model simulations, each with a slightly different set of parameter values, for each scenario. For example, to estimate the area contributing recharge to the Main Pumphouse wells

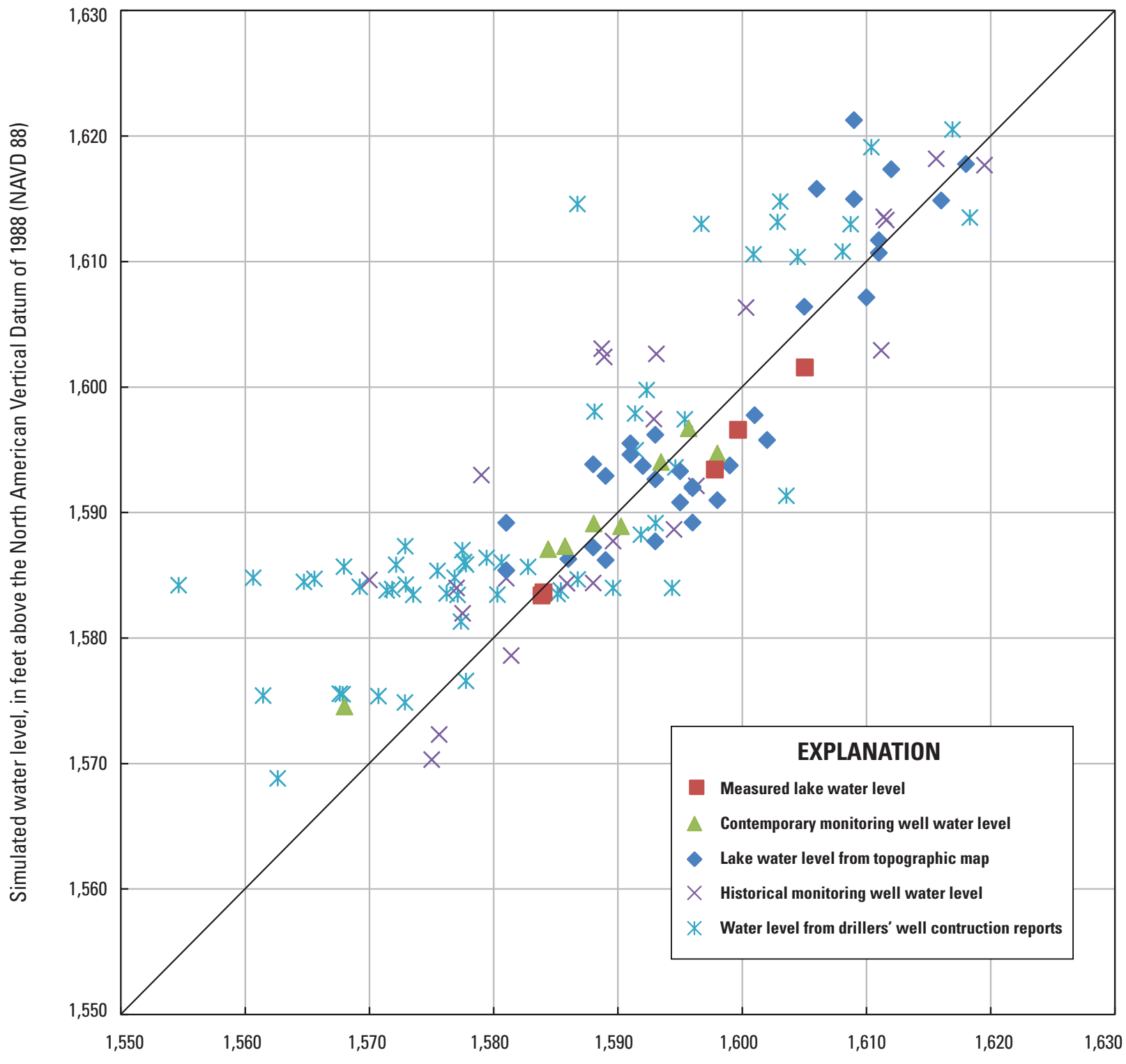

Target water level, in feet above the North American Vertical Datum of 1988 (NAVD 88)

Figure 5. Simulated water levels in relation to target water levels, Lac du Flambeau Reservation, Wisconsin. 


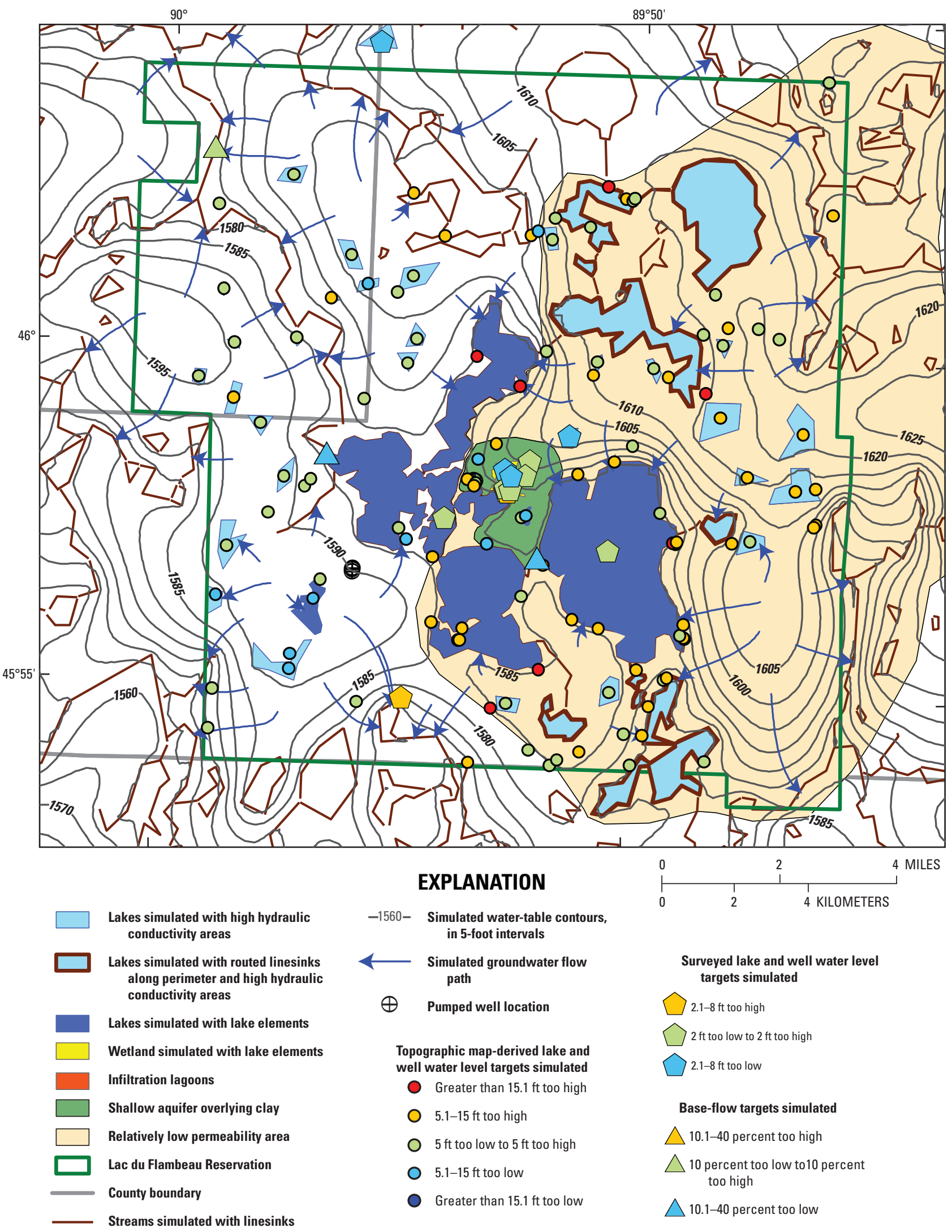

Figure 6. Simulated groundwater flow directions and computed difference between simulated and target water levels and base flows, Lac du Flambeau Reservation, Wisconsin. 
(fig. 4), each parameter in table 1 was randomly adjusted up or down from the calibrated value one thousand times followed by a single solution of the GFLOW model. For this Monte Carlo analysis, parameter values typically ranged over more than an order of magnitude from the calibrated values. A map of the probability that a well would capture water recharged in adjacent areas was then produced by evaluating the percentage of model solutions for which an individual particle of water that started at the water table flowed through the aquifer and was captured by the well. This type of visual representation of probability accounts for uncertainty in the parameter values as they relate to the particular scenario of interest. A similar uncertainty analysis using Monte Carlo techniques was performed to estimate the probability of wastewater presence in the aquifer down-gradient of wastewater infiltration lagoons near the Village of Lac du Flambeau. Application and results of the Monte Carlo simulations are further described in the sections "Application of the Model to Simulate Areas Contributing Recharge to Existing Wells" and "Application of the Model to Simulate Flow of Wastewater from Infiltration Lagoons."

\section{Simulation of Groundwater/Surface- Water Interaction}

Analytic element models are well suited for simulating groundwater/surface-water interactions because much of the groundwater flow system computations are based on the properties and configuration of linesinks that represent surface-water features (Haitjema, 1995). Some advantages of simulating groundwater/surface-water interactions in a model include the ability to (1) estimate the amount of water moving through each component of the hydrologic cycle for groundwater-dominated systems; (2) evaluate the sources of water to points and areas of interest, such as wells and lakes; and (3) evaluate effects of hydrologic stressors, such as wet and dry weather cycles (and groundwater pumping), on the integrated hydrologic system. For example, figure 7 diagrammatically illustrates the direction and magnitude of water movement, known as the hydrologic cycle, for portions of the Bear River watershed and Fence Lake on the Lac du Flambeau Reservation.

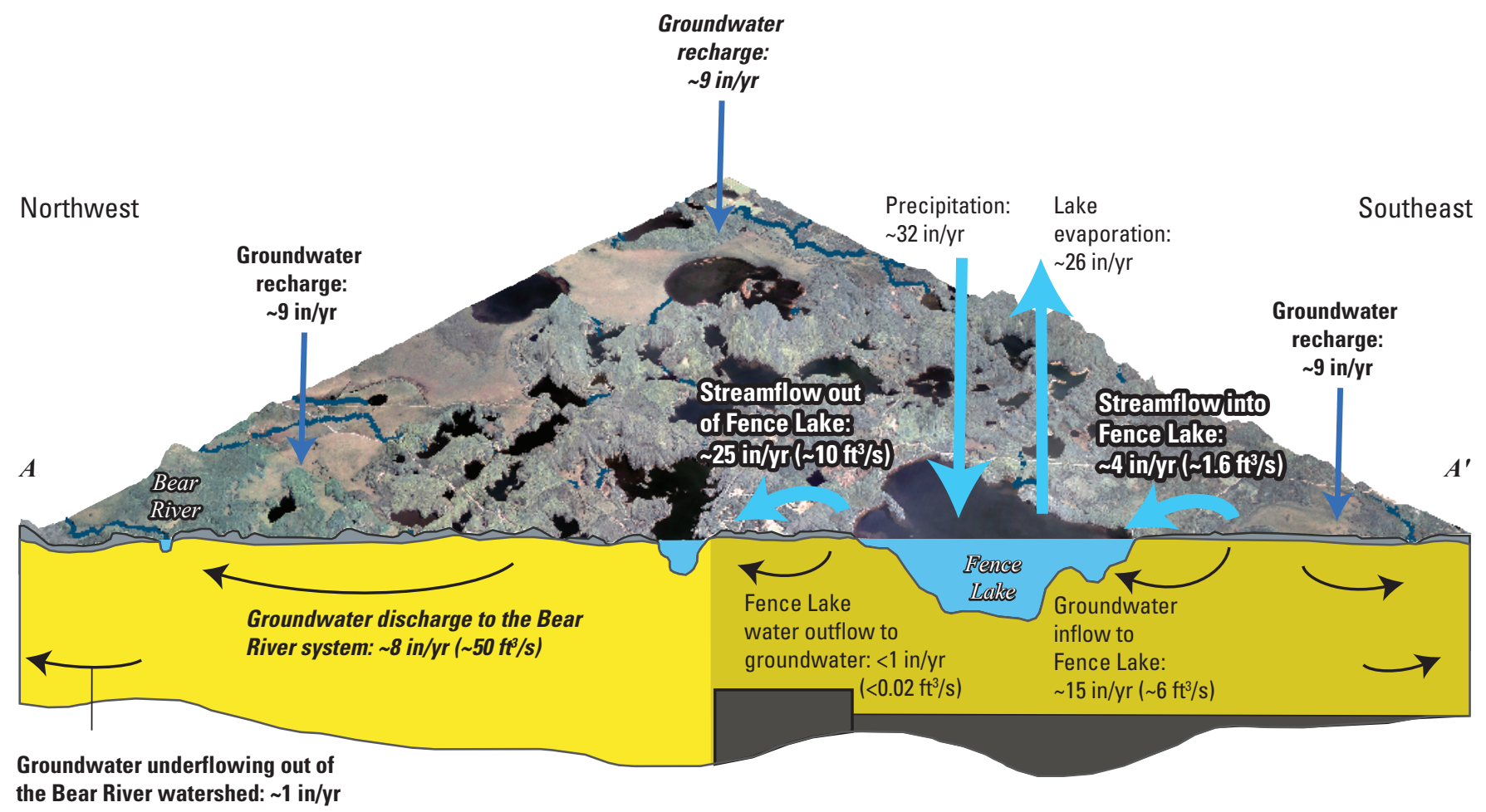

NOT TO SCALE; VERTICAL DIMENSION EXAGGERATED

Figure 7. Diagram of the hydrologic cycle for the northeastern part of the Lac du Flambeau Reservation, Wisconsin. 
Water budgets for Fence Lake, the combined Flambeau lakes (Flambeau, Pokegama, Long Interlaken, Moss, and Crawling Stone Lakes), Tippecanoe Lake, Mindy Lake, and two wetlands near the lagoons were simulated for average (calibrated) conditions using the model (table 3). It is important to reiterate that although the groundwater flow model is well suited for simulating groundwater/surface-water interactions, it is not designed to simulate surface-water processes such as flooding and runoff. That is, simulated streamflow into and out of lakes in the model only considered base flow-that portion of streamflow that is derived from groundwater. As such, streamflow contributions to the lakes in this model did not include stormflows or overland runoff. This was accomplished by adjusting the flow calibration targets to represent only the long-term average base flow component (as described in the section "Model calibration"). Thus, the total water budget, and particularly the quantity from streamflow, is expected to be slightly underestimated by the model. However, runoff and stormflow are expected to be relatively minor components of the lake water budgets, given the low topographic relief in the watershed and the relatively permeable soils. Therefore, because groundwater is a major source for surface-water features on the Reservation, model results can be used to identify the major sources and sinks of water for the lakes.

Results of the model illustrate differences in the sources of water to lakes. Table 3 contains water budget components for lakes that were simulated with lake elements, or lakes for which the simulated lake stage and water budget were computed concurrently. Water entering Fence, Tippecanoe, and Mindy Lakes is primarily from precipitation (63 to 82 percent) with additional inflow from groundwater (18 to 30 percent) and streamflow (0 to 8 percent). Sources of water entering the combined Flambeau lakes, all of which are surface-water drainage lakes, are approximately equally distributed among precipitation (34 percent), streamflow (37 percent), and groundwater (29 percent). Water entering the wetlands near the wastewater lagoons is primarily from groundwater $(60$ to 72 percent) and secondarily from precipitation ( 28 to 40 percent); there is no simulated streamflow into the wetlands. This analysis agrees with common hydrologic understanding that stream base flow entering and leaving the lakes is a larger component of the total lake water budget for lakes at relatively lower elevations; precipitation and groundwater are larger components of the water budget for lakes and wetlands at relatively higher elevations (headwater areas).

Potential effects of extended wet and dry periods were evaluated by adjusting precipitation and groundwater recharge in the model and comparing the resulting simulated lake stage and water budgets to stages and water budgets from the calibrated model. Dripps and Bradbury (2010) used a Soil Water Balance code (Dripps and Bradbury, 2007; Westenbroek and others, 2010) to estimate groundwater recharge over a 5-year period (1996-2000) in the area around Trout Lake, Wisconsin, a nearby watershed east of the Reservation. Annual precipitation ranged from 22.4 inches in 1998 to 38.6 inches in 1996, with corresponding areally averaged annual recharge ranging from 5.1 inches in 1998 to 15.3 inches in 1996 . These values represent a 30-percent decrease to a 21 -percent increase in precipitation, respectively, from the long-term average of 32 inches per year (as described in the section "Description of the GFLOW model"). The recharge fluctuation calculated by Dripps and Bradbury (2010) represents a 55-percent decrease and a 66-percent increase in recharge, respectively, from the calibrated recharge of $9.2 \mathrm{in} / \mathrm{yr}$ for the Reservation. The steady-state groundwater/surface-water flow system was simulated using these dry-year and wet-year values to evaluate effects on the lake water budgets and lake stage for lakes and wetlands simulated with lake elements (table 3). Steady-state assumptions were used and are to be considered an extreme case for this analysis. This is because the hydrologic system's natural response to wet or dry cycles is mitigated by groundwater storage that is neglected in this steady-state analysis. That is, the steady-state assumption represents perpetually dry or perpetually wet conditions, whereas such conditions typically last a few years or decades in the natural system, and the system's response to extreme weather patterns is gradual and partially subdued by groundwater storage in the aquifer. It is expected that multiple decades of continual wet or dry conditions would be needed to have the system approach hydrologic steady-state conditions.

Simulated lake stages changed by less than $1 \mathrm{ft}$ for the drainage lakes (Fence Lake and the combined Flambeau lakes) between the calibrated model and the wet and dry scenarios. This small change in simulated stage is reasonable for drainage lakes because the lake stage is maintained as a result of a corresponding change in flow through the outlet channel of drainage lakes. That is, as water levels rise or fall in a drainage lake, outflows change in a similar fashion. Although all sources of water into the lakes increased for the wet scenario, tributary inflow increased by a greater amount than precipitation and groundwater discharge. Likewise, increased stream outflow accounted for all of the increased inflows. For the dry scenario, all sources to and sinks from the lakes decreased, but stream inflow and outflow decreased by the largest amount (and streamflow into Fence Lake nearly ceased). The relatively small changes in groundwater discharge to the drainage lakes between wet and dry scenarios illustrate the stability of the groundwater system compared to the streamflow system and the groundwater system's capacity to partially mitigate variability associated with atmospheric drivers (precipitation and recharge).

Simulated lake stages changed by about 2 to $11 \mathrm{ft}$ for seepage lakes and wetlands-Tippecanoe and Mindy Lakes, and the wetlands near the lagoons - between the calibrated model and the wet and dry scenarios. Unlike the changes in the water budget for drainage lakes, groundwater inflow to the seepage lakes and the northern wetland decreased during the wet scenario and increased during the dry scenario. This was caused by the relatively large change in precipitation, which raised the lake stage relative to the water table. This natural mitigation of water-level fluctuation associated with groundwater inflows, along with the relatively large changes in stage 
Table 3. Simulated lake water budgets for the calibrated model and wet and dry scenarios in Lac du Flambeau, Wisconsin.

[in/yr, inches per year; ft, feet]

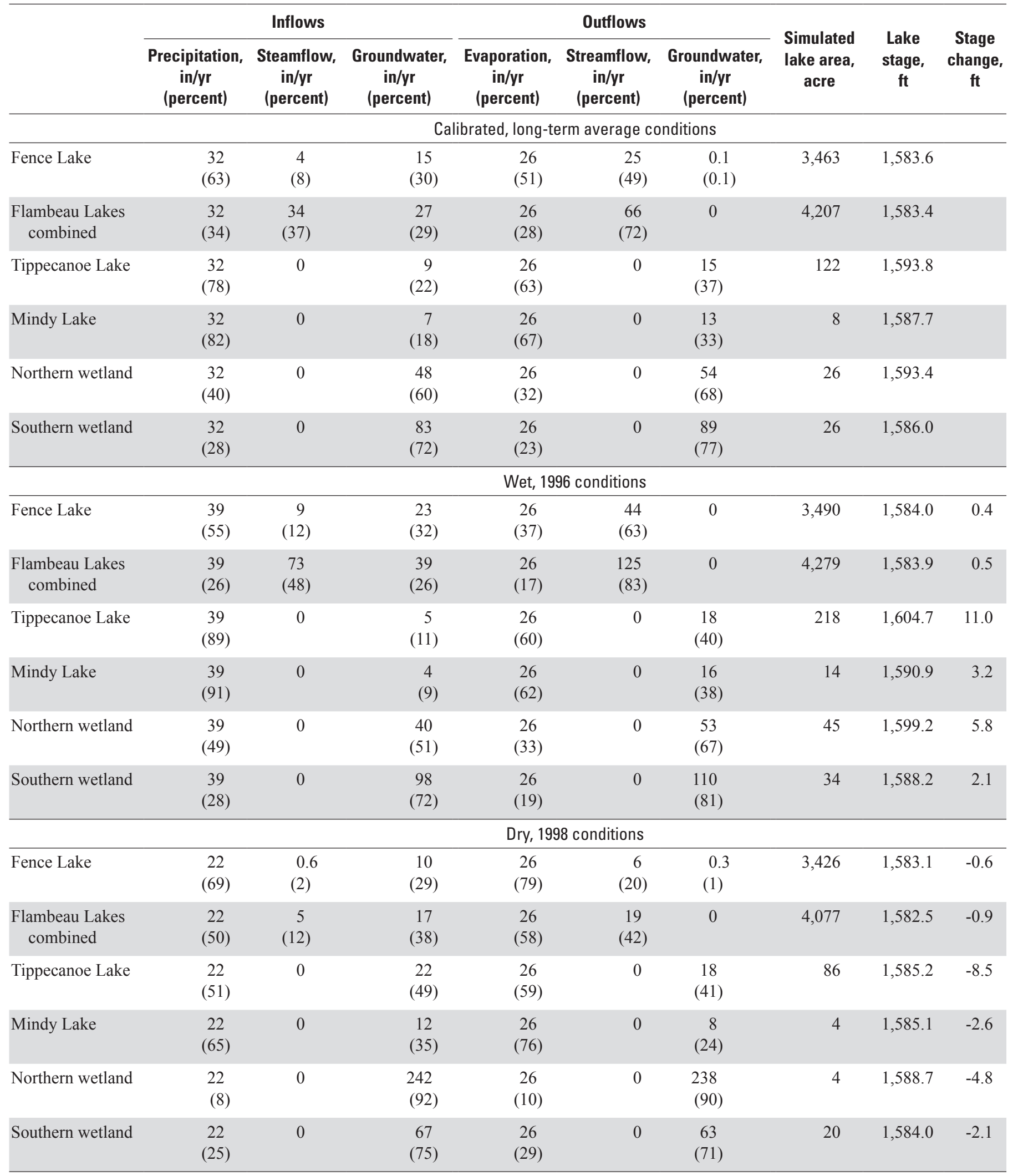


compared to the drainage lakes, also illustrates the importance of groundwater levels and groundwater/surface-water interaction to buffer lake water levels during prolonged wet and dry periods.

The pattern of groundwater inflow to the southern wetland differed from that of the northern wetland and the other seepage lakes, in that groundwater inflow increased for the wet scenario and decreased for the dry scenario. It is anticipated that this difference is due to the proximity of the southern wetland to Moss Lake (part of the combined Flambeau lakes), which experienced less than $1 \mathrm{ft}$ of water-level fluctuation from the calibrated solution. Although the water level in the southern wetland fluctuated more ( $2 \mathrm{ft}$ ) than in Moss Lake, this fluctuation was likely less than the fluctuation of the water table, causing additional groundwater discharge to the wetland during the wet scenario and less discharge during the dry scenario. This difference in the response of the southern wetland to wet and dry scenarios compared with the northern wetland and seepage lakes further illustrates the importance of understanding the position of an individual surface-water body within the regional surface-water and groundwater flow systems when interpreting changes in water levels associated with atmospheric drivers.

\section{Simulation of Areas Contributing Recharge to Existing Wells}

Areas contributing recharge to drinking-water supply wells on the Reservation were delineated by forward tracking of particles from the water table to the wells; this, in combination with Monte Carlo techniques, enabled maps to be produced showing of the probability of capture for each well nest. That is, a range of model parameter values were sampled using a Latin Hypercube approach (Starn and Bagtzoglou, 2012) to construct thousands of parameter realizations. For every realization, or combination of parameter values, the model was re-solved and simulated particle tracks were evaluated as to whether each particle was or was not captured by a pumped well. Upon completion of all realizations, the percentage of realizations for which a particle was captured by a well was computed for each particle. The starting location for each particle was then plotted on a map, with the color code indicating the percentage of realizations, or probability, that the particle would be captured by a nearby well (figs. 8-11). Time-based areas contributing recharge to the wells (for example, 5-yr, 10 -yr, etc.) also are shown in figures 8-11 as computed using the calibrated set of parameters. Steady-state (no change over time) pumping conditions were used to simulate two scenarios for each pumphouse location - a base pumping scenario with rates that reflect current (2010) pumpage from the groundwater system and a high pumping scenario in which the rate was set at the expected water demand for 2035, as estimated by the Tribe. Pumping rates for individual wells were estimated as a percentage of the total water demand for the Reservation on the basis of the maximum pumping capacity of each well.

The results of the Monte Carlo simulations show a relatively sharp spatial contrast from areas of high probability of capture to low probability of capture for wells at the Main Pumphouse (figs. 8-9) and West Pumphouse (figs. 10-11) under current and future pumping scenarios. This sharp gradation in probability is a result of the assumed steady-state conditions, as well as the well-constrained groundwater flow system that results from the presence of regionally important boundary conditions (for example, Crawling Stone, Fence, Flambeau, and Pokegama Lakes). That is, the large lakes that occupy much of the Reservation have strong control over groundwater flow directions, and reasonable changes to modeling parameters have only moderate capacity to modify the flow patterns near these large lakes. For the Main Pumphouse wells, most of the area contributing recharge to the wells occurs downgradient of a large wetland that extends between the wells and the wastewater infiltration lagoons (the northern wetland in table 3). Water leaves the wetland along its western border, enters the aquifer, and flows toward the wells. Probability of capture was not shown inside the wetland because the wetland was simulated as a boundary condition (a lake element). That is, water movement is not simulated within lakes or wetlands represented by lake elements. Moreover, these water bodies are assumed to be fully mixed, so the origin of water to the wetland is indiscernible for particle tracking purposes. Nonetheless, the relatively high simulated sediment resistance for the wetland (table 1) allows for simulated groundwater flow paths to be traced beneath the wetland. That is, the sediment resistance limits the extent to which heads in the aquifer are affected by the wetland, such that hydraulic influence of the wetland is not considered to fully penetrate the aquifer. Given this construction of the model, figures 8 and 9 show areas east of the wetland where water has a low to moderate probability of being captured by the Main Pumphouse wells. Indeed, a few particles that originate at the mounded water table beneath the infiltration lagoons illustrate a small potential for the Main Pumphouse wells to capture infiltrated wastewater.

For the West Pumphouse wells, most of the area contributing recharge occurs between the wells and Tippecanoe Lake. Areas west of Tippecanoe Lake show a small potential for capture by the West Pumphouse wells. In general, the contrast from areas of high probability of capture to low probability is relatively sharp, though not as sharp as for the Main Pumphouse wells. This is likely due to the fact that the West Pumphouse wells are located farther from major surfacewater bodies and closer to a groundwater divide than the Main Pumphouse wells, meaning that fluctuations in water levels resulting from changes in recharge or simulated variations in hydraulic conductivity may have the potential to alter groundwater flow patterns to a greater extent near the West Pumphouse wells than near the Main Pumphouse wells. 


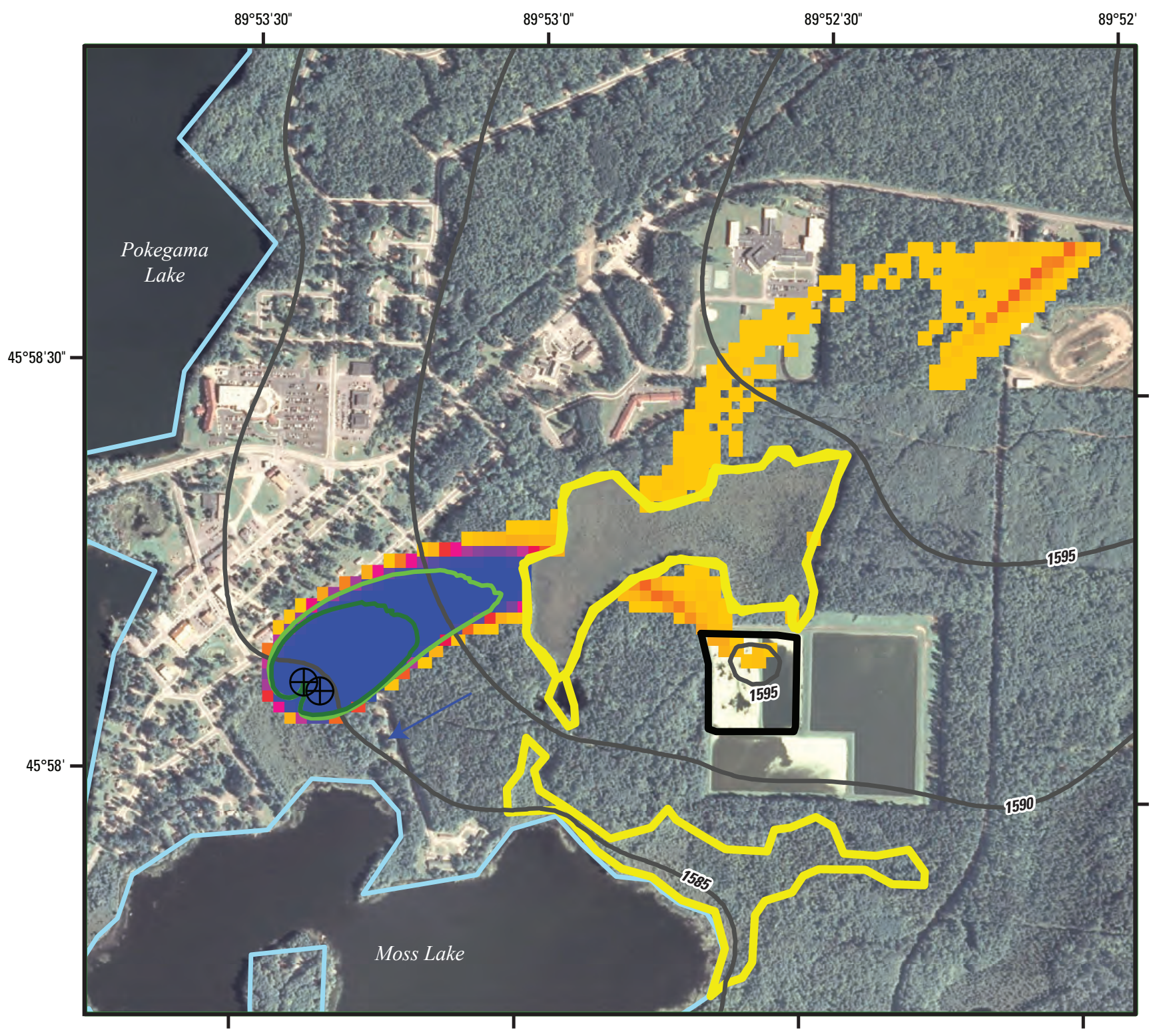

Base map from National Agriculture Imagery Program (NAIP), 2010

\section{EXPLANATION}
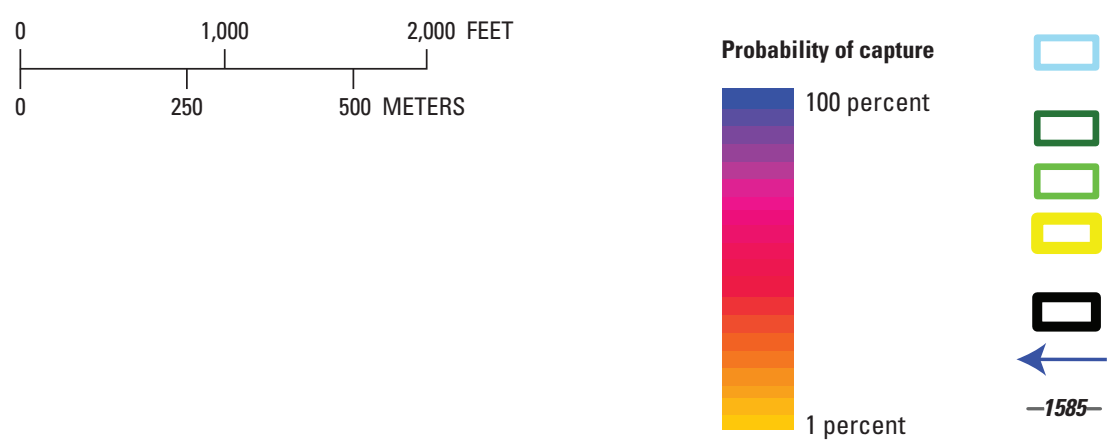

Lake simulated with lake-water budget linesinks

5-year area contributing recharge

10-year area contributing recharge

Wetland simulated with lake-water budget linesinks

Infiltration lagoons

General direction of groundwater flow

Simulated water table contours using calibrated parameters, in 5-foot intervals

$\bigoplus$ Pumped well location

Figure 8. Simulated area contributing recharge to wells pumped at the current (2010) average rate at the Main Pumphouse site and the probability of capture for particles of water recharging the water table, Lac du Flambeau Reservation, Wisconsin. 


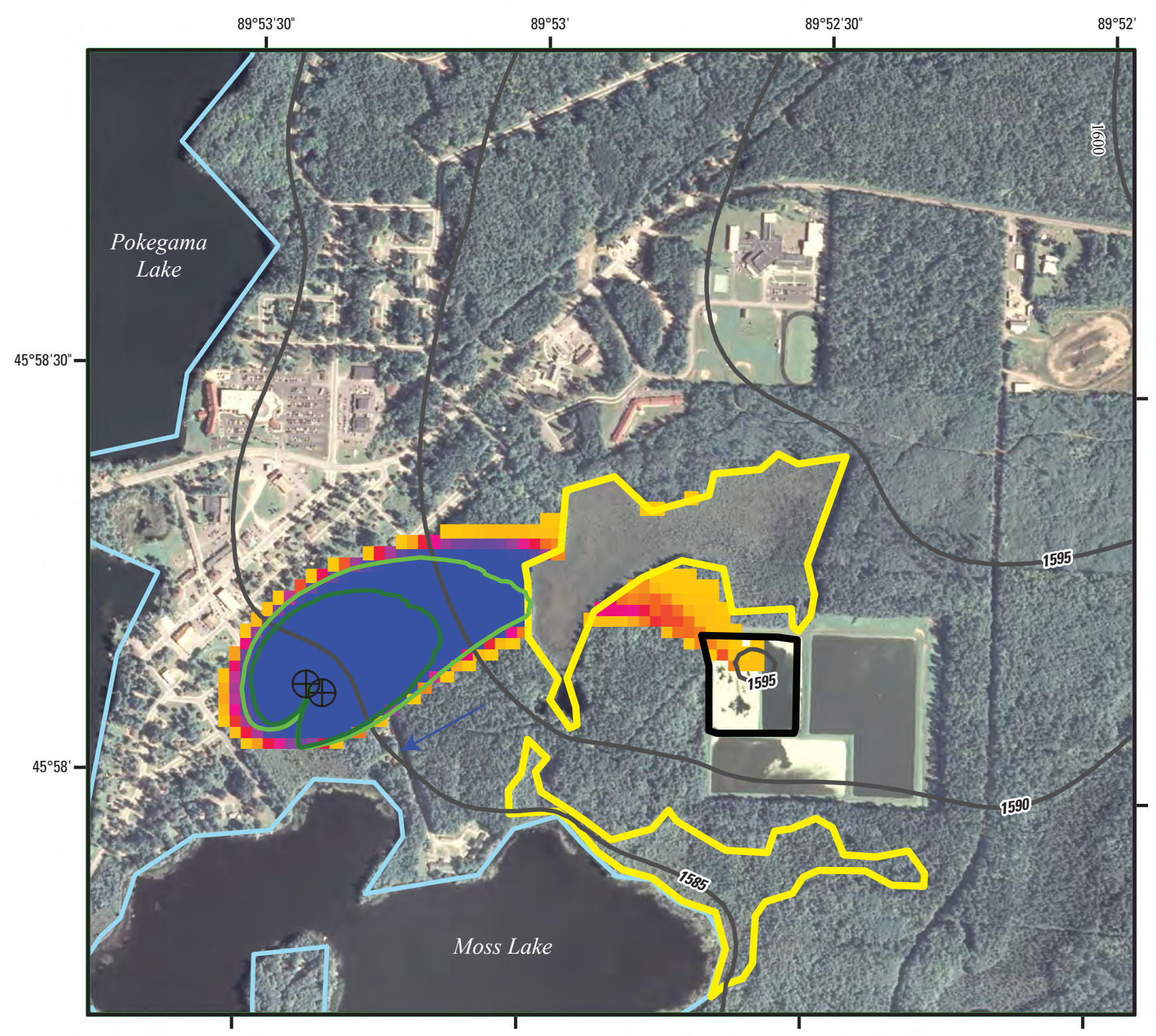

Base map from National Agriculture Imagery Program (NAIP), 2010

\section{EXPLANATION}
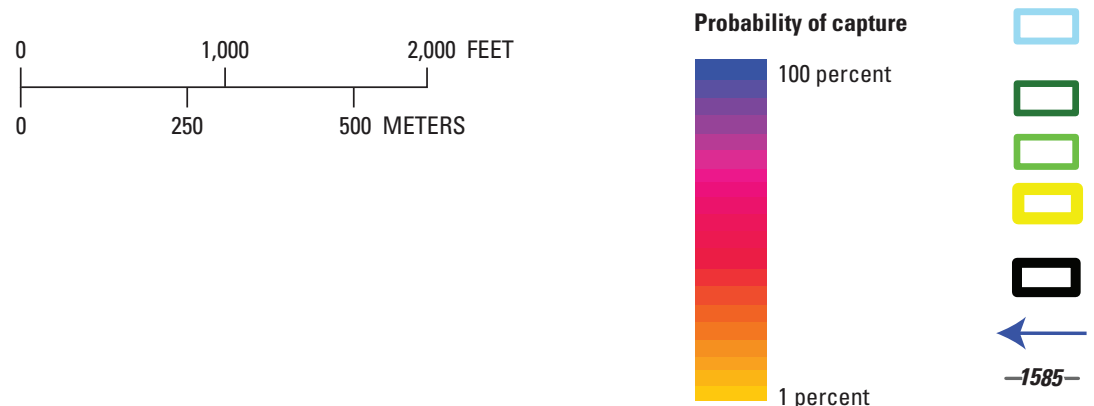
Lake simulated with lake-water budget
linesinks

5-year area contributing recharge

10-year area contributing recharge

Wetland simulated with lake-water budget linesinks

Infiltration lagoons

General direction of groundwater flow

-1585- Simulated water table contours using calibrated parameters, in 5-foot intervals

$\bigoplus \quad$ Pumped well location

Figure 9. Simulated area contributing recharge to wells pumped at the expected future rate at the Main Pumphouse site and the probability of capture for particles of water recharging the water table, Lac du Flambeau Reservation, Wisconsin. 


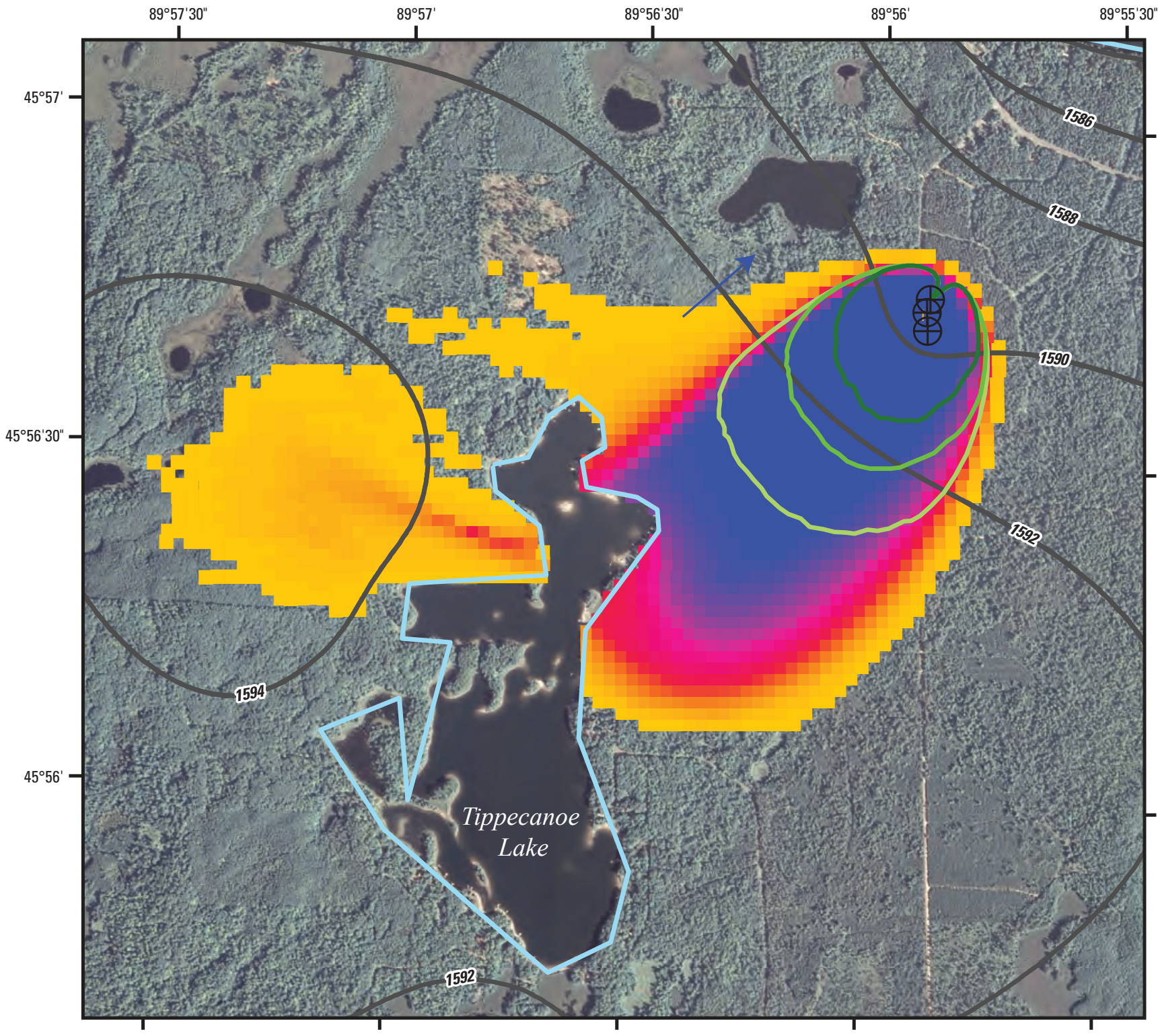

Base map from National Agriculture Imagery Program (NAIP), 2010

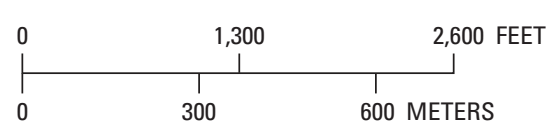

EXPLANATION

Probability of capture

100 percent
Lake simulated with lake-water budget linesinks

5-year area contributing recharge

10-year area contributing recharge

20-year area contributing recharge

General direction of groundwater flow

-1592_ Simulated water table contours using

calibrated parameters, in 2-foot intervals

$\bigoplus \quad$ Pumped well location

1 percent

Figure 10. Simulated area contributing recharge to wells pumped at the current (2010) average rate at the West Pumphouse site and the probability of capture for particles of water recharging the water table, Lac du Flambeau Reservation, Wisconsin. 


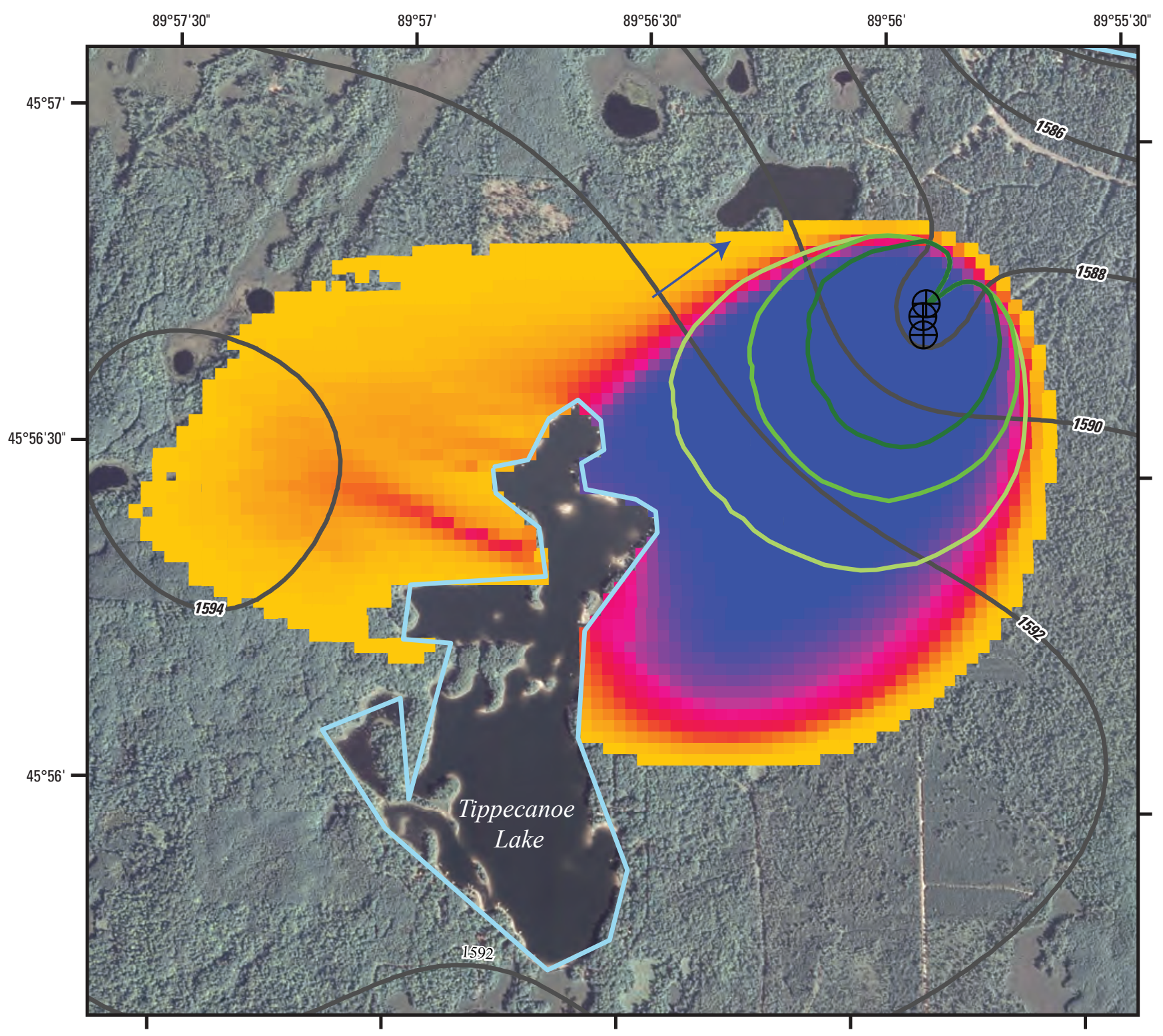

Base map from National Agriculture Imagery Program (NAIP), 2010

\section{EXPLANATION}

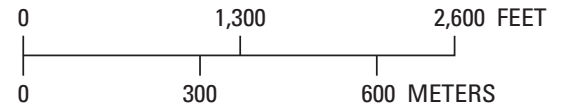

Probability of capture
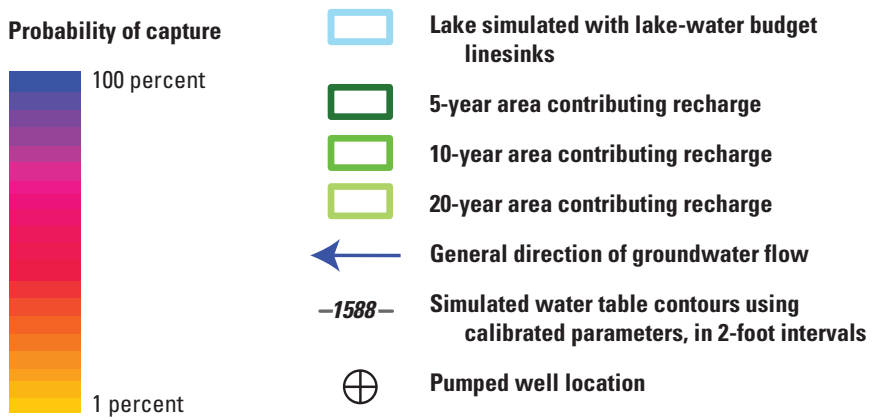

Figure 11. Simulated area contributing recharge to wells pumped at the expected future rate at the West Pumphouse site and the probability of capture for particles of water recharging the water table, Lac du Flambeau Reservation, Wisconsin. 
Estimates of the time required for a particle of water within the area contributing recharge to reach the wells (for example, the 5-year or 10-year area contributing recharge) were calculated using the calibrated model parameters and an assumed effective porosity of 0.2 . While this value is on the lower end of the typical range of total porosity for sanddominated aquifers (Freeze and Cherry, 1979), it is a reasonable estimate of effective porosity for sand-dominated aquifers. Effective porosity is the portion of the aquifer through which fluids can flow and is often lower than the total porosity, which is simply the ratio of void space to total aquifer volume, including the solid particles. Areas contributing recharge were delineated at 5-, 10- and 20-year intervals.

\section{Simulation of Flow of Wastewater from Infiltration Lagoons}

The Lac du Flambeau Band of Lake Superior Chippewa (Tribe) and Indian Health Service are evaluating management options for handling the disposal of wastewater in the Reservation. Currently, wastewater is treated in four lagoons east of the Village of Lac du Flambeau, two of which infiltrate water into the shallow groundwater flow system (the east and south treatment lagoons are assumed to be impermeable because they are lined with clay and polyvinyl chloride, or PVC). Infiltrated wastewater from the two lagoons was simulated using a specified recharge inhomogeneity in the groundwater flow model, with the rate of infiltration computed from estimates of average annual wastewater discharge into the lagoons provided by the Tribe (Scott Valliere, Lac du Flambeau Band of Lake Superior Chippewa, written commun., 2011). Four alternative scenarios also were simulated to evaluate the effects of (1) infiltration of wastewater through a 100-foot long diffuser at the bottom of a wetland south of the current lagoons, (2) discharge of wastewater into a small lake (Mindy Lake) between Moss Lake and Fence Lake, south of the current lagoons, (3) infiltration of wastewater through a hypothetical lagoon south of the current lagoons, and (4) infiltration of wastewater through a hypothetical lagoon northeast of the current lagoons. Infiltration rates for the alternative scenarios were adjusted on the basis of the size of the feature in order to maintain the same amount of infiltration of water as is produced by the existing lagoons.

The horizontal extents of the wastewater plume downgradient from the current infiltration lagoons and the alternative scenario sources were simulated using particle tracking, with particles traced from the water table to a terminal surfacewater body. The method considered only advective flow from the sources; no attempt was made to evaluate contaminant mass or concentration transport. That is, source concentrations, dispersion, sorption, and geochemical reactions were all ignored. Instead, results were posed in terms of the probability that one or more particles would flow through a synthetic grid cell in the area down-gradient of the lagoons. Monte Carlo techniques were used to estimate the probable horizontal extent of the wastewater plume given a range of parameter values that were informed by covariance matrices from the PEST calibration and variance estimates for parameters that were fixed during calibration. The range of model parameter values were sampled using a Latin Hypercube approach (Starn and Bagtzoglou, 2012) to construct thousands of possible parameter realizations for the Monte Carlo simulations.

The horizontal extents of the probable wastewater plumes were evaluated according to whether one or more particles passed through individual cells that formed a synthetic grid covering the aquifer in the area of interest. The method is susceptible to the level of detail used to represent the synthetic grid and the number of particles released from the wastewater source (Juckem and Fienen, 2013). Thus, results for source tracking of the wastewater plume are considered to be qualitative only. Nonetheless, it is expected that the qualitative results will be of use for evaluating management alternatives. For example, areas with extreme probability (values near 100 percent or zero percent) are expected to be less sensitive to the number of particles and level of discretization than areas with more uncertain probabilities (near 50 percent computed probability). Moreover, this qualitative approach could be used to identify wells or surface-water bodies in areas of concern for particular scenarios. For these areas of concern, the problem could be reformulated into an "area contributing recharge" analysis for a well or surface-water body of interest, which is not sensitive to the number of simulated particles or the resolution of a synthetic grid.

Wastewater infiltrated from the current wastewater infiltration lagoons flows radially away from the lagoons, and then flows predominantly south toward Moss Lake as it integrates with the regional groundwater flow system (fig. 12). Most of the infiltrated wastewater eventually discharges to Moss Lake, the southern wetland between the lagoons and Moss Lake, or a small tributary stream (fig. 12) that originates west of the lagoons and flows into Moss Lake. However, some of the infiltrated wastewater is simulated as having a moderate probability of flowing beneath the northern wetland that lies between the lagoons and the Main Pumphouse wells. That is, there appears to be a low probability that some wastewater could be captured by the Main Pumphouse wells (fig. 12), which is similar to results from the "area contributing recharge" analysis (fig. 8). 


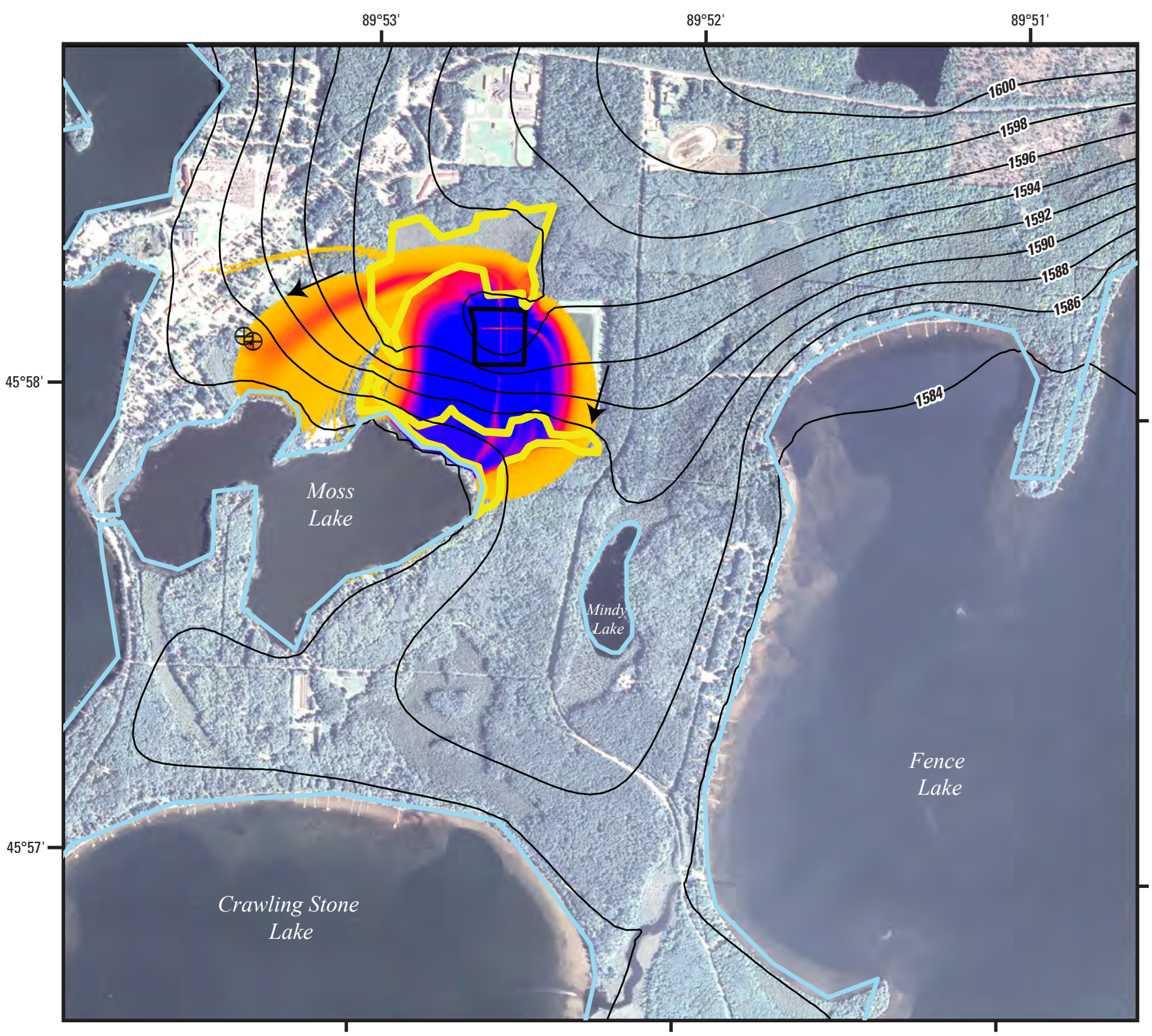

Base map from National Agriculture Imagery Program (NAIP), 2010

EXPLANATION

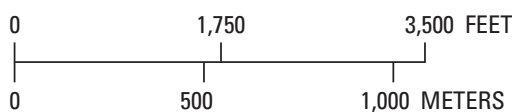

Probability of plume extent

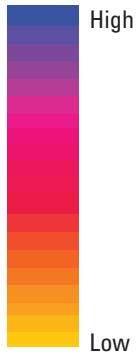

Lake simulated with lake-water budget linesinks

Wetland simulated with lake-water budget linesinks

Infiltration lagoons

General direction of groundwater flow

-1586 - Simulated water table contours using calibrated parameters in 2-foot intervals

$\bigoplus \quad$ Pumped well location

Figure 12. Simulated probability of the plume extent from the wastewater-treatment lagoons under current (2010) conditions, Lac du Flambeau Reservation, Wisconsin. These results are considered to be qualitative because methods for the wastewater-plume-extent scenarios are sensitive to the number of mathematical water particles used to represent infiltrating wastewater and the level of detail in the synthetic grid used for the probability analysis. 
The model also was used to simulate four hypothetical alternative management scenarios for discharging wastewater. For these scenarios, infiltration from the current infiltration lagoons was eliminated and instead, the same volume of water was applied to (1) a hypothetical 100-ft-long diffuser conceptualized to be $10 \mathrm{ft}$ below a wetland south of the current lagoons (fig. 13); (2) Mindy Lake, the small lake south of the lagoons between Moss and Fence Lakes (fig. 14); (3) a hypothetical lagoon between Moss and Mindy Lakes, south of the current lagoons (fig. 15); or (4) a hypothetical lagoon northeast of the current lagoons on the east side of Thorofare Road (fig. 16).

The wetland diffuser scenario (fig. 13) was simulated in the model through the addition of a 100-ft-long specifieddischarge linesink below the southern wetland, which was simulated as a lake element. In two-dimensional models, such as GFLOW, the discharge from the diffuser is applied uniformly from the top to bottom of the aquifer. However, the diffuser was effectively simulated below the wetland owing to the sediment resistance simulated for the lake elements representing the wetland. This sediment resistance limits interaction between the wetland and groundwater system. Moreover, simulated particles surrounding the diffuser were started $10 \mathrm{ft}$ below the calibrated water table to approximate flow from a diffuser set $10 \mathrm{ft}$ below the wetland surface. Direct application of the wastewater to the simulated lake element representing the wetland would not allow for discrete placement of the wastewater, as was intended with the 100-ft diffuser. No existing information was available to provide the model with representative values for the vertical hydraulic conductivity of wetland sediments in the Reservation. However, the wetland resistance parameter (sediment thickness divided by vertical hydraulic conductivity; table 1) was expected to be an important parameter for evaluating the predictive uncertainty of the wastewater plume; thus, a range of wetland resistance values was tested during Monte Carlo simulations.

Wastewater simulated to infiltrate into the ground through the hypothetical 100-ft-long diffuser below the southern wetland appears to discharge directly to the southern wetland in the immediate area of the diffuser (fig. 13). Results of the simulation indicate that diffusing wastewater into the aquifer in this way would likely exceed the capacity of the aquifer to transmit the wastewater below ground, and thus, much of the wastewater would be expected to resurface within the wetland and flow overland through the wetland prior to discharging to Moss Lake. Such overland flow is not represented with the groundwater flow model and, thus, is not apparent in figure 13. Results also show a low probability that some wastewater from the diffuser could remain in the aquifer and flow west toward Moss Lake, south toward Mindy Lake, and east toward Fence Lake. Outcomes from this possible management scenario would also likely be sensitive to on-the-ground installation and site characteristics that were not considered during the scenario simulation.
For the second scenario, hypothetical wastewater discharge to Mindy Lake was simulated by applying the average daily wastewater volume to the lake elements representing Mindy Lake. Applying the wastewater to the entire string of lake elements builds upon the assumption that all water in the lake is fully mixed. In addition, use of lake elements ensured that the addition of wastewater would produce a proportional increase in the simulated lake stage, thereby modifying the local groundwater flow patterns. Simulated wastewater discharged to Mindy Lake appears to spread radially in the aquifer over a large area between Moss, Fence, and Crawling Stone Lakes (fig. 14). Head contours illustrate that a groundwater mound forms below the lake, which produces the radial spreading. The high probability of extensive radial spreading suggests that the groundwater flow patterns for this scenario are relatively insensitive to the varied model parameters (table 1). This insensitivity is attributed to the effect and proximity of extensive low-elevation lakes that surround the simulated plume. That is, Fence, Crawling Stone, and Moss Lakes are major groundwater discharge features (table 3 ) that dominate the local groundwater flow pattern, regardless of recharge and aquifer properties. The two thin "strips" of apparent low probability east of Mindy Lake are likely an artifact of the linesink discretization and not the result of any physical properties or processes.

The third scenario involved simulating wastewater discharge from a hypothetical lagoon south of the current lagoons and between Moss and Mindy Lakes. Simulated probabilities illustrate that most of the infiltrated wastewater is expected to discharge to Moss Lake with successively lower probabilities of discharge to the wetland along the eastern shore of Moss Lake, as well as Mindy Lake and Fence Lake to the east. Results indicate a relatively higher probability of wastewater in the aquifer upgradient (west) of Mindy Lake than in the area downgradient (east) of Mindy Lake, indicating that a portion of the wastewater discharges to Mindy Lake with less total wastewater flowing below Mindy Lake toward Fence Lake.

The fourth scenario involved simulating wastewater discharge from a hypothetical lagoon northeast of the current lagoons. Simulated probabilities illustrate that most of the infiltrated wastewater is expected to discharge to Fence Lake with successively lower probabilities of discharge to the southern and northern wetlands near the current lagoons. This scenario, like the others, assumes that all wastewater discharge to the existing lagoons is halted. It is expected that this scenario would be more affected than the three previously described hypothetical scenarios by concurrent operation with the existing lagoons. Such a concurrent operation would have more effect on simulated results for this scenario than the first three hypothetical scenarios because of the proximity of the hypothetical lagoon to the current lagoons and the lack of a surface-water boundary between the hypothetical and current lagoons. 


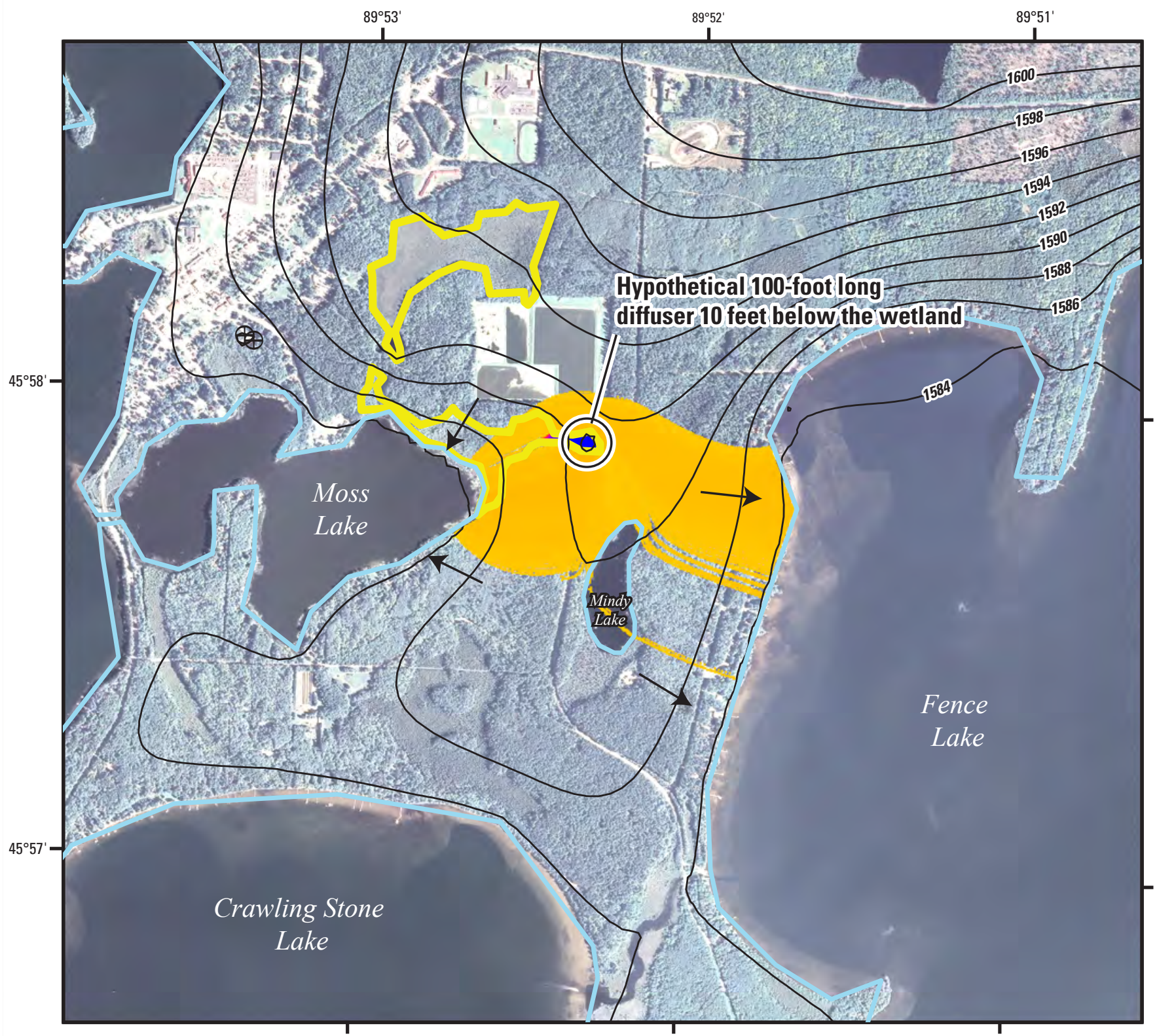

Base map from National Agriculture Imagery Program (NAIP), 2010

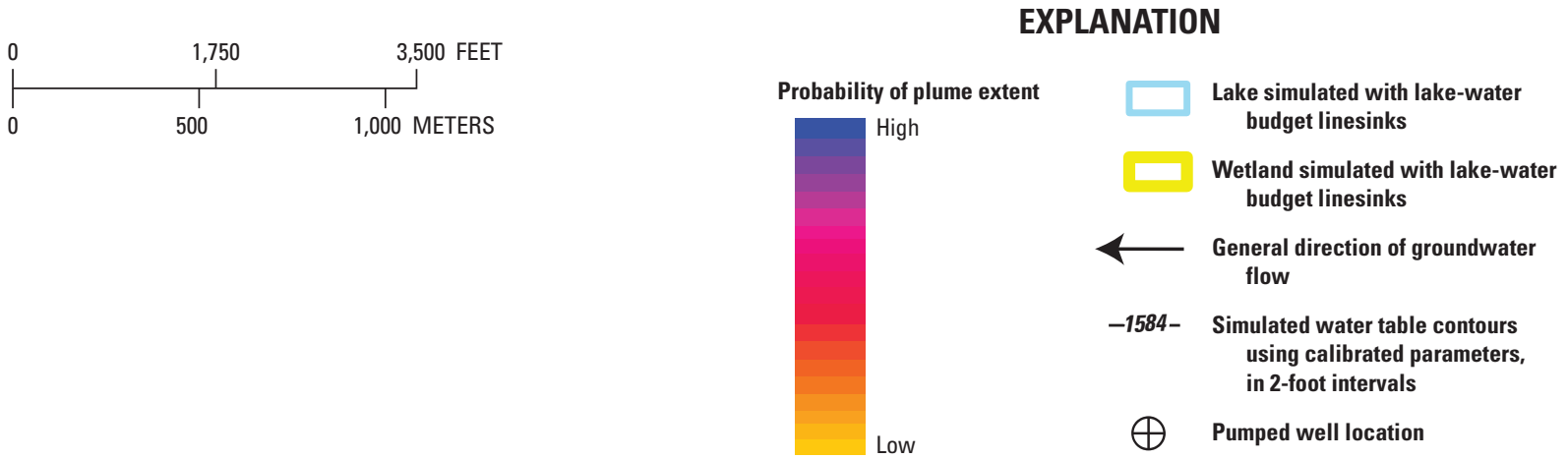

Figure 13. Simulated probability of the plume extent for a scenario with waste water discharged through a 100-foot-long diffuser 10 feet beneath a wetland east of Moss Lake, Lac du Flambeau Reservation, Wisconsin. These results are considered to be qualitative because methods for the wastewater-plume-extent scenarios are sensitive to the number of mathematical water particles used to represent infiltrating wastewater and the level of detail in the synthetic grid used for the probability analysis. 


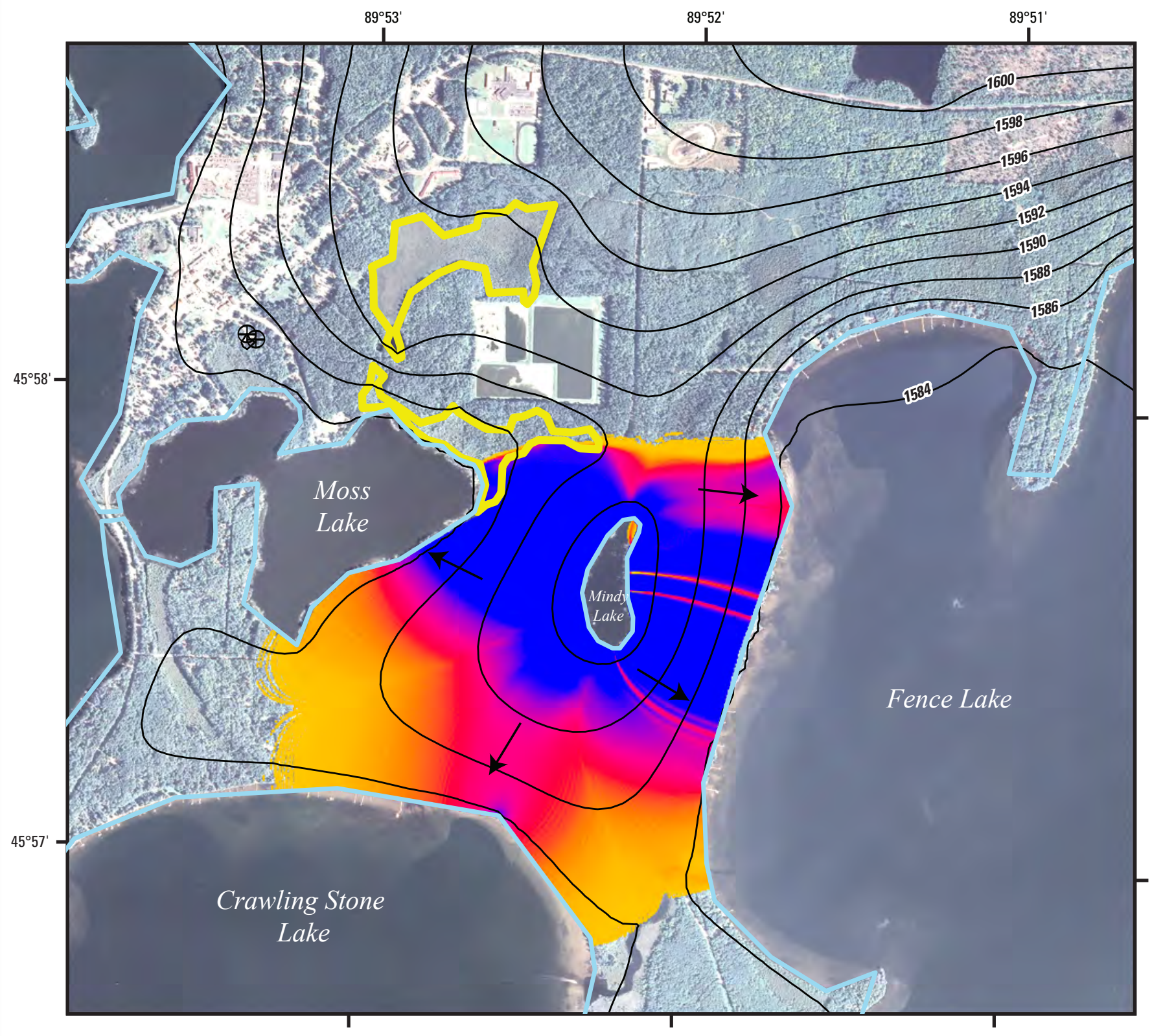

Base map from National Agriculture Imagery Program (NAIP), 2010

EXPLANATION

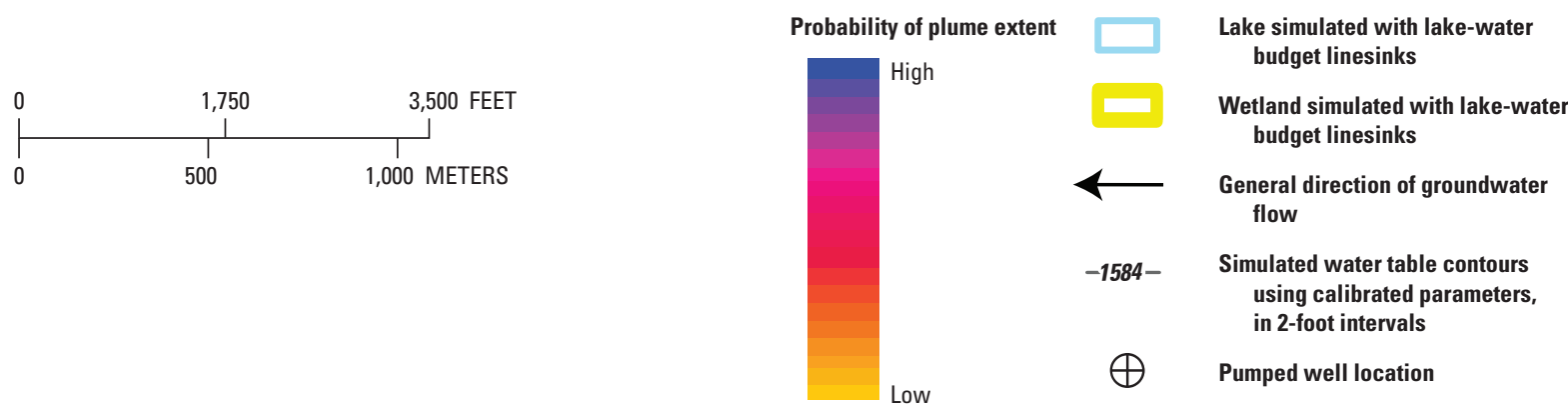

Figure 14. Simulated probability of the plume extent for a scenario with wastewater discharged to Mindy Lake, Lac du Flambeau Reservation, Wisconsin. These results are considered to be qualitative because methods for the wastewater-plume-extent scenarios are sensitive to the number of mathematical water particles used to represent infiltrating wastewater and the level of detail in the synthetic grid used for the probability analysis. 


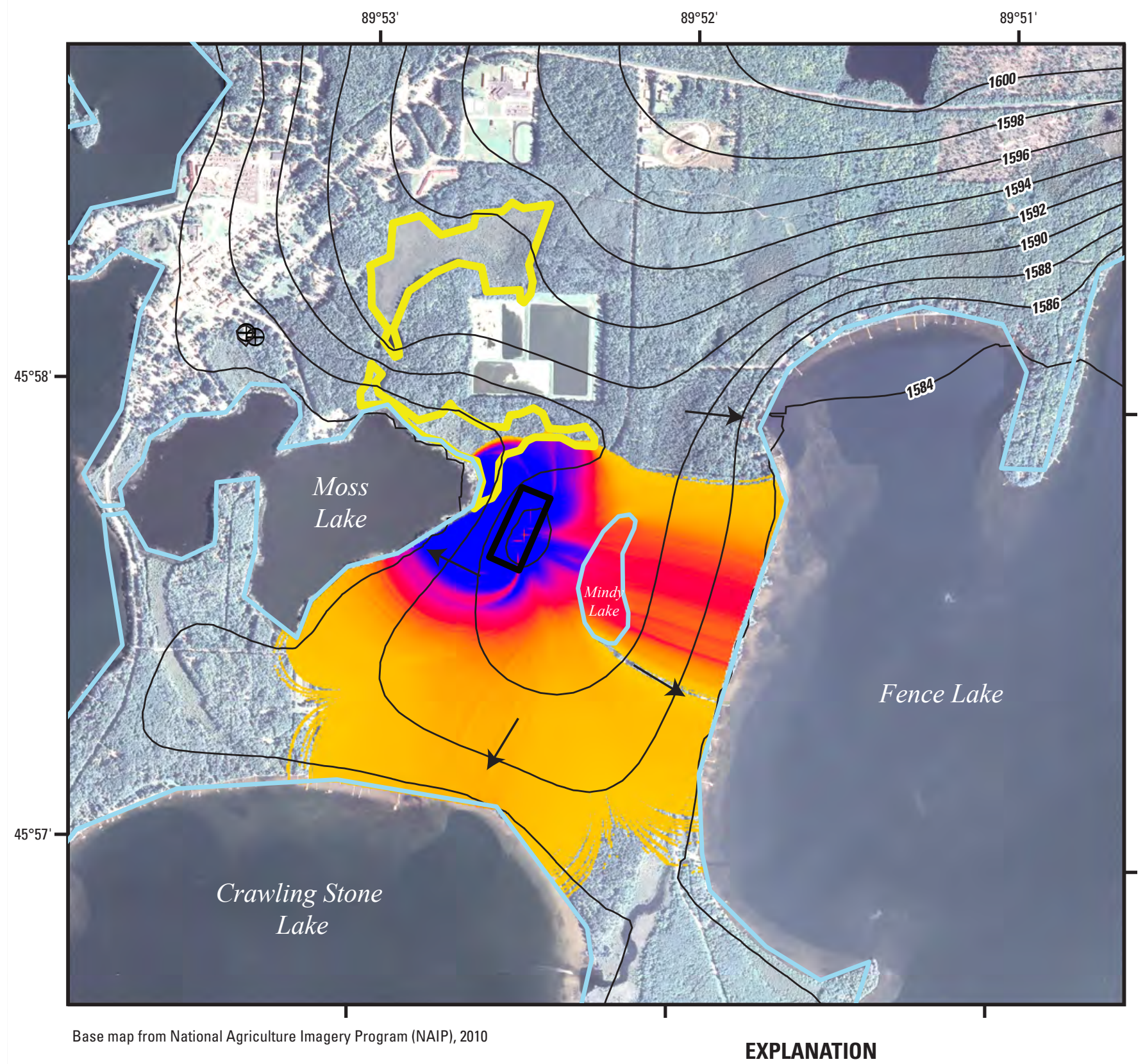

$\left.\left.\right|_{0} ^{0} \stackrel{1,750}{\mid}\right|_{1,000 \text { METERS }} ^{3,500 \text { FEET }}$

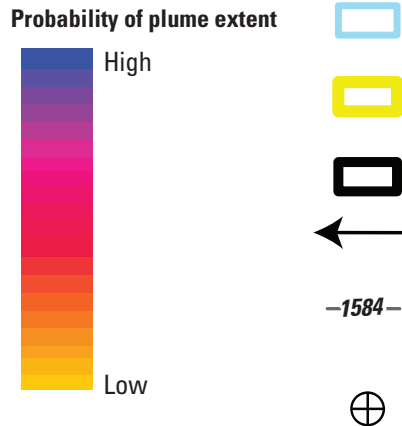
Lake simulated with lake-water
budget linesinks

Wetland simulated with lake-water budget linesinks

Infiltration lagoons

General direction of groundwater flow

Simulated water table contours using calibrated parameters, in 2-foot intervals

Pumped well location

Figure 15. Simulated probability of the plume extent for a scenario with wastewater discharged from a hypothetical infiltration lagoon south of the current lagoons, Lac du Flambeau Reservation, Wisconsin. These results are considered to be qualitative because methods for the wastewater-plume-extent scenarios are sensitive to the number of mathematical water particles used to represent infiltrating wastewater and the level of detail in the synthetic grid used for the probability analysis. 


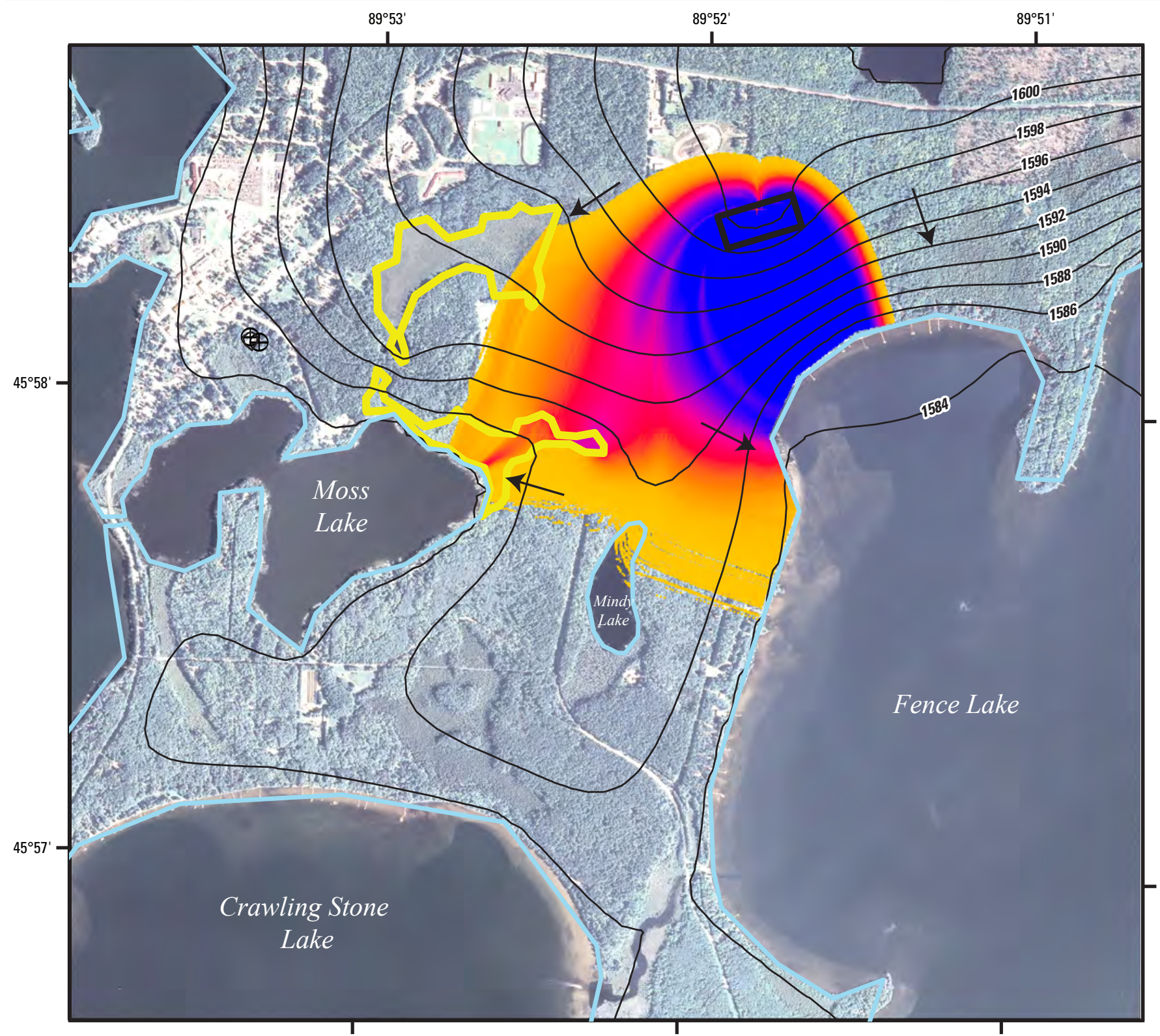

Base map from National Agriculture Imagery Program (NAIP), 2010

\section{EXPLANATION}

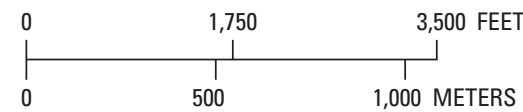

Probability of plume extent

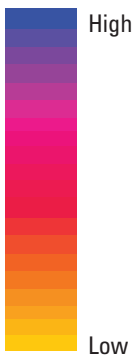

Lake simulated with lake-water budget linesinks

Wetland simulated with lake-water budget linesinks

Infiltration lagoons

General direction of groundwater flow

-1584- Simulated water table contours using calibrated parameters, in 2-foot intervals

$\bigoplus \quad$ Pumped well location

Figure 16. Simulated probability of the plume extent for a scenario with wastewater discharged from a hypothetical infiltration lagoon northeast of the current lagoons, Lac du Flambeau Reservation, Wisconsin. These results are considered to be qualitative because methods for the wastewater-plume-extent scenarios are sensitive to the number of mathematical water particles used to represent infiltrating wastewater and the level of detail in the synthetic grid used for the probability analysis. 
Finally, in order to evaluate water table mounding resulting from the existing infiltration lagoons, the model was used to compare current (2010) conditions in which wastewater is infiltrated through the lagoons (the calibrated model) with a scenario without any wastewater infiltration (fig. 17). Comparison of simulated water-table contours indicate that the infiltrated wastewater may mound the water table approximately $4 \mathrm{ft}$ beneath the lagoons, with diminishing levels of mounding outward from the lagoons. For example, mounding resulting from wastewater infiltration may be about $2 \mathrm{ft}$ near the southern end of the northern wetland and a similar amount near the southwest corner of the southern lagoon. Removing infiltrated wastewater from the model did not change the simulated water level of Fence Lake or the combined Flambeau Lakes.

\section{Assumptions and Limitations}

Given the relatively high hydraulic conductivity of the aquifer, relatively high groundwater-recharge rate, and presence of perennial streams, the groundwater and surface-water systems are assumed to be in close hydrologic connection in the study area. As a result, elevations of surface-water features are assumed to approximate heads in the underlying groundwater system. An areal two-dimensional groundwater-flow model was assumed to be appropriate for this application because the aquifer is relatively thin, areally extensive, and assumed to have uniform hydraulic conductivity with depth in each hydraulic conductivity zone. Steady-state conditions were assumed to be appropriate for this system because hydraulic conductivity is high and distances between surfacewater features are relatively small; these characteristics help dampen the effects of periodic transient stresses applied to the system (Haitjema, 1995). Steady-state assumptions, which ignore groundwater release from storage, are expected to simulate a greater system response to hydrologic stresses (such as drought or pumping) than transient simulations.

Limitations of the model arise from these assumptions; specifically, local three-dimensional flow and transient system response expected near wells, infiltration lagoons, and shorelines of surface-water features are not represented. In addition, local features of the groundwater system (for example, local variations in hydraulic conductivity and recharge) are only approximated by using large zones. These limitations add to the uncertainty associated with estimating areas contributing recharge to wells and mapping wastewater plume extents (Franke and others, 1999). However, the Monte Carlo methods that were employed for this study take uncertainty associated with parameter values partially into account. Other uncertainties resulting from the model structure were not evaluated (for example, alternative distributions of parameters or alternative conceptual models); therefore, some additional uncertainty in simulated results is expected beyond that presented in this report.
Results of Monte Carlo simulations for tracking of wastewater from the infiltration lagoons and four additional scenarios are sensitive to user-specified settings (figs. 12-16). These settings include the number of simulated particles $(1,000)$ and the resolution of the synthetic grid ( $16 \mathrm{ft}$ for the examples shown in this report). As a consequence, results from all source-water tracking simulations (figs. 12-16) are considered qualitative and are to be used with caution for informing management decisions. This source tracking approach may be useful for identifying areas of concern downgradient from infiltrated wastewater. A quantitative evaluation of the probability that a well or stream captures wastewater could then be performed for the newly identified areas of concern by utilizing the "area contributing recharge" method.

Better estimates of components of the hydrologic cycle on the Reservation could be obtained through long-term monitoring of tributary streams or through more sophisticated simulation of the hydrologic system with a fully coupled groundwater/surface-water model, such as GSFLOW (Markstrom and others, 2008). Likewise, the one-time measurements of outflow from the lakes and lake water levels (July 2010), which were used to inform the model calibration, provide a useful check on the simulated water budgets. However, additional measurements over a range of weather conditions and water levels would be needed to reduce uncertainty in the simulated water budgets for these lakes. It is also important to note that simulated stream outflows depend on a specified stage/ outflow relationship for each lake element (Fence Lake and the combined Flambeau Lakes). Only two measurements for each lake were available for evaluating this relationship. The first measurement is from flow and stage values measured on July 29, 2010, for both simulated drainage lakes. In addition, the sill elevations of the outlet channels were measured at that time. The sill elevation represents the lowest point along the highest channel cross section and represents the water level at which zero outflow would occur. Thus, only zero flow at the sill elevation and the flow and stage on July 29, 2010, were used to produce a relationship between simulated lake stage and outflow for these lakes. This limited understanding of the stage/outflow relationship means that the simulated results are likely better suited for comparing and learning from simulated relative hydrologic changes resulting from drought and wet conditions than for management decisions requiring discrete, absolute values. Although the results are intended for heuristic purposes, additional information on the stage/outflow relationship would improve simulated results. In addition, the wet and dry periods simulated for this report represent sustained multi-year periods of wet and dry conditions, therefore, shorter duration atmospheric stress (a few months or years of wet or dry conditions) will not be well represented by the steady-state assumption used in the modeling described in this report.

Estimated areas contributing recharge within specified times of travel (for example, the 5-year and 10-year areas contributing recharge) are estimated from model results with little observational data to constrain the simulated groundwater ages. That is, groundwater age, or travel time, is dependent 

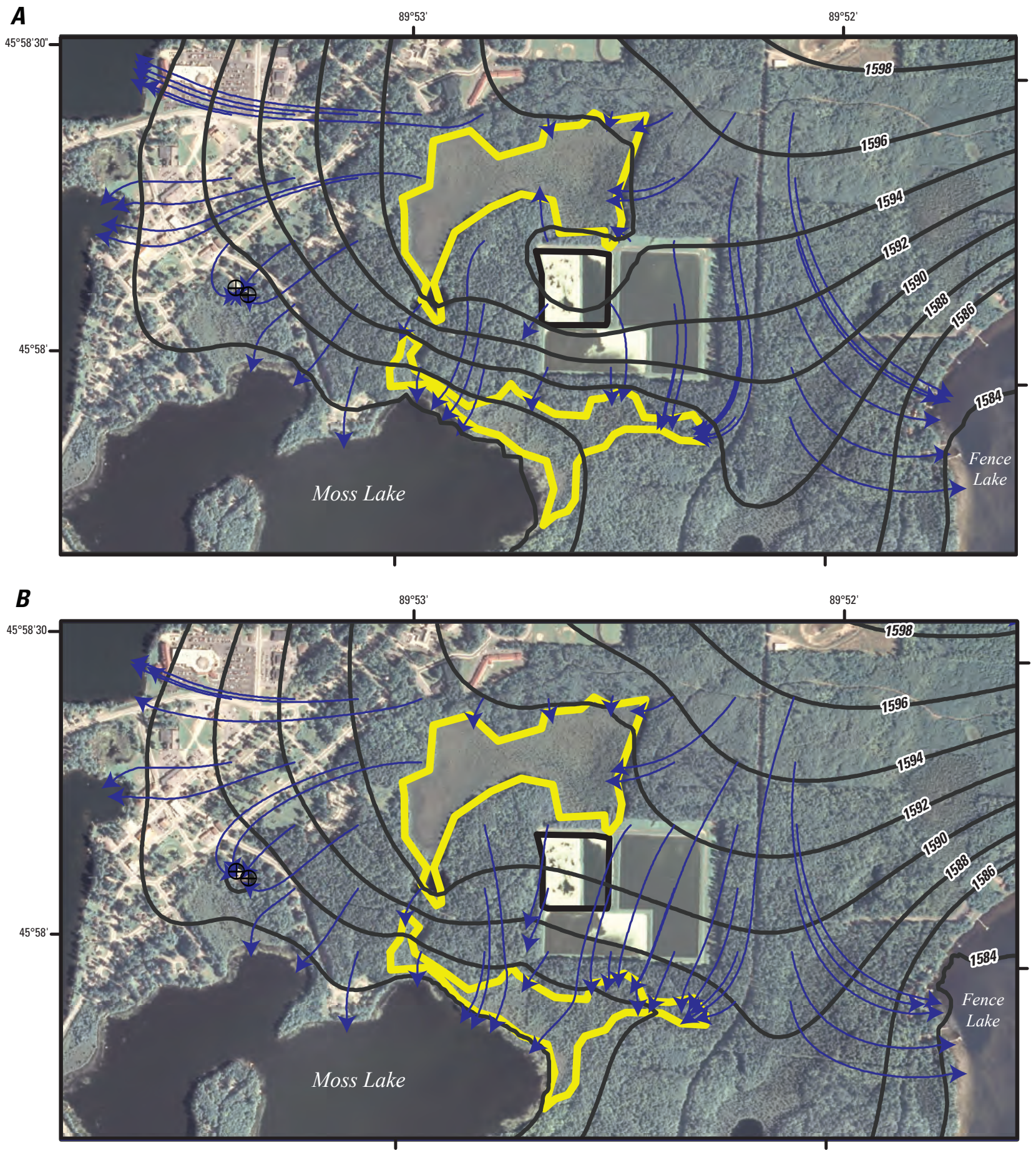

Base map from National Agriculture Imagery Program (NAIP), 2010

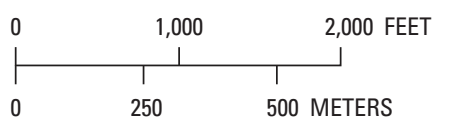

EXPLANATION

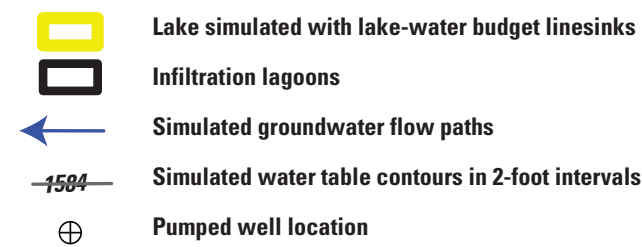

Figure 17. Simulated groundwater flow paths from the wastewater-treatment lagoon area $(A)$ with current $(2010)$ wastewater infiltration rates and $(B)$ zero infiltration at the lagoons, Lac du Flambeau Reservation, Wisconsin. 
upon the recharge rate, porosity of the aquifer, saturated thickness of the aquifer, and specifics of the well construction, such as the vertical location of the screened interval within the aquifer (Eberts and others, 2013). While calibration data helped in informing recharge rates and saturated thickness of the aquifer, little information is available on the porosity of the aquifer. Moreover the wells were simulated as being fully penetrating, thus ignoring the true screened interval. Improved estimates of age-specific contributing areas would require refinement of the model and collection of groundwater age tracers (for example, tritium, tritium/helium ratios, chlorofluorocarbon, sulfur hexafluoride, and carbon-14) that could be used to evaluate simulated age distributions at the wells.

\section{Summary and Conclusions}

The Lac du Flambeau Band of Lake Superior Chippewa and Indian Health Service are interested in improving the understanding of groundwater flow and interaction with surface water, and are concerned about the fate of wastewater that is infiltrated from treatment lagoons and the potential for contamination of water-supply wells on the Lac du Flambeau Reservation (Reservation). This report describes water-quality data for samples collected near a system of wastewatertreatment lagoons and the construction and calibration of a regional groundwater flow model used to simulate the shallow groundwater flow system beneath the Reservation. The model was used to simulate groundwater/surface-water interaction, including calculation of lake water budgets, delineation of areas contributing recharge to pumped wells, and estimation of the extent of infiltrated wastewater from treatment lagoons. The study area is located in southwest Vilas County and southeast Iron County, Wisconsin, and overlies a relatively thin glacial aquifer. Seepage and drainage lakes are common in the area and affect groundwater flow patterns on the Reservation. Major conclusions from this study include the following:

1. Analytical results of groundwater and surface-water samples collected downgradient from the infiltration lagoons show greater levels of ammonia and dissolved phosphorus than those in groundwater samples collected from a "background" well upgradient from the lagoons. Of the 24 wastewater indicator chemicals detected in three downgradient wells and a small downgradient stream, the most common were DEET and isophorone. The highest concentrations relative to the detection limit or blank water concentrations were for camphor and p-cresol (24 and 22 times the detection limit, respectively) in the stream sample. These results support results from the model that indicate infiltrated wastewater is moving to the southwest from the lagoons toward Moss Lake.
2. Potential effects of extended wet and dry periods were evaluated by adjusting precipitation and groundwater recharge in the steady-state model, and comparing the resulting simulated water budgets to water budgets from the calibrated model. Simulated lake water budgets and water-level changes illustrate the importance of understanding the position of a lake within the hydrologic system (headwater or downstream), the type of lake (surface-water drainage or seepage lake), and the importance of groundwater in mitigating the effects of largescale changes in weather patterns on lake levels. That is, relatively small simulated changes in water level from the calibrated model (less than $1 \mathrm{ft}$ ) for large drainage lakes is related to the ability of water to flow out of the lakes through outlet channels. For drainage lakes, higher water levels result in more surface-water outflow. Wetlands and seepage lakes adjacent to large drainage lakes exhibited water-level fluctuations that were smaller than simulated water-level fluctuations for wetlands and seepage lakes located closer to headwater areas, far from large drainage lakes. Water-level changes in headwater wetlands and seepage lakes appear to be most sensitive to prolonged wet and dry patterns. Depending on the lake type and location, results illustrate that groundwater exchange with lakes and wetlands can dampen some potential water-level fluctuation resulting from atmospheric drivers (precipitation and evaporation).

3. Areas contributing recharge to drinking-water supply wells on the Lac du Flambeau Reservation were delineated by tracking model particles from the water table to wells in combination with Monte Carlo techniques, which produced maps of the probability of capture for each well nest. Simulations were performed for current (2010) pumping rates and rates estimated for 2035. The simulations show a relatively sharp spatial contrast from areas of high probability of capture to areas of low probability of capture for wells at the Main Pumphouse and West Pumphouse locations under current (2010) and future pumping scenarios. For the Main Pumphouse wells, most of the area contributing recharge to the wells is downgradient from a large wetland, between the wells and the wastewater infiltration lagoons, although results show the wells have at least a small potential for capturing infiltrated wastewater. For the West Pumphouse wells, most of the area contributing recharge is between the wells and Tippecanoe Lake. 
4. Qualitative Monte Carlo assessments of wastewater plume extents were simulated by evaluating the probability that each forward-tracked particle from infiltration lagoons would intersect an individual cell of a synthetic grid applied across the down-gradient aquifer. Results show that wastewater infiltrated from the currently operating lagoons flows predominantly south toward Moss Lake as it integrates with the regional groundwater flow system. Some of the infiltrated wastewater is simulated as having a low probability of flowing to the Main Pumphouse wells, although most of the infiltrated wastewater eventually discharges to Moss Lake or a small tributary stream that originates west of the lagoons and flows into Moss Lake. Also, comparison of simulated water-table contours indicate that the lagoons may cause the water table to mound approximately $4 \mathrm{ft}$ below the lagoons, with diminishing levels of mounding outward from the lagoons.

5. The qualitative Monte Carlo wastewater-plume-extent assessment method also was used to simulate hypothetical alternative management scenarios for discharging wastewater. Wastewater hypothetically infiltrated into the ground through a 100-ft-long diffuser below the southern wetland appears to discharge directly to the wetland, at which point, it is presumed, the water would flow overland to Moss Lake. Wastewater hypothetically discharged to Mindy Lake appears to spread radially over a large area between Moss, Fence, and Crawling Stone Lakes. Wastewater from a hypothetical lagoon south of the current lagoons was simulated as having a high probability of discharging to Moss Lake and a moderate probability of flowing east through the aquifer and discharging to Mindy and Fence Lakes. Wastewater from a hypothetical lagoon northeast of the current lagoons was simulated as having a high probability of discharging to Fence Lake and a moderate probability of flowing southwest through the aquifer to the southern wetland and Moss Lake. Simulated results of the wastewater-plume-extent scenarios are sensitive to the number of mathematical water particles used to represent infiltrating wastewater and the level of detail in the synthetic grid used for the probability analysis. Therefore, simulated probabilities of wastewater plume extents are considered to be qualitative only. Moreover, the Monte Carlo methods used in this study to evaluate uncertainty associated with parameter values do not allow for evaluation of alternative distributions of parameters or alternative conceptual models, and therefore, some level of uncertainty in simulated results is unavoidable. Nonetheless, the uncertainty analyses were developed from the basis of a physically based groundwater flow model and covariances developed through calibration to extensive target data sets, and are expected to provide managers with useful information for making informed management decisions.

\section{References Cited}

Attig, J.W., 1985, Pleistocene geology of Vilas County, Wisconsin: Wisconsin Geological and Natural History Survey Information Circular 50, $32 \mathrm{p}$.

Batten, W.G., and R.A. Lidwin, 1996, Water resources of the Lac du Flambeau Indian Reservation, Wisconsin, 1981-86; U.S. Geological Survey Water-Resources Investigations Report 94-4025, 42 p.

California Office of Environmental Health Hazard Assessment, 2001, Chronic toxicity summary-Isophorone: Determination of noncancer chronic reference exposure levels Bacht 2B, accessed September 14, 2012, at http://www. oehha.ca.gov/air/chronic_rels/pdf/isophorone.pdf.

Dempster, G.R., Jr., 1990, National Water Information System user's manual_-Volume 2, chapter 3, Automated Data Processing System: U.S. Geological Survey Open-File Report 90-116 [variously paged].

Doherty, J., 2011, PEST: Model-independent parameter estimation user manual (5th ed.) and addendum: Brisbane, Queensland, Australia, Watermark Numerical Computing, $336 \mathrm{p}$.

Dripps W.R., Bradbury K.R., 2007, A simple, daily soil-water balance model for estimating the spatial and temporal distribution of groundwater recharge in temperate humid areas. Hydrogeology Journal, v. 15, no. 3, p. 433-444.

Dripps, W.R., and K.R. Bradbury, 2010, The spatial and temporal variability of groundwater recharge in a forested basin in northern Wisconsin: Hydrological Processes, v. 24, p. 383-392.

Franke, O.L., Reilly, T.E., Pollock, D.W., and LaBaugh, J.W., 1999, Estimating areas contributing recharge to wells: Lessons from previous studies. U.S. Geological Survey Circular 1174, 14 p.

Freeze R.A. and J.A. Cherry, 1979, Groundwater: Prentice-Hall, 604 p.

Haitjema, H.M., 1995, Analytic element modeling of groundwater: San Diego, Academic Press, 394 p.

Haitjema, H.M., 2005, Modeling lake-groundwater interactions in GFLOW, accessed September 14, 2012, at http:// www.haitjema.com/documents/Modelinglakegroundwaterint eractionsinGFLOW.pdf 
Hunt, R.J., 2006, Ground water modeling applications using the analytic element method: Ground Water, v. 44, no. 1, p. 5-14.

Hunt, R.J., Anderson, M.P., and Kelson, V.A., 1998, Improving a complex finite-difference ground water flow model through the use of an analytic element screening model: Ground Water, v. 36, no. 6, p.1011-1017.

Hunt, R.J., Haitjema, H.M., Krohelski, J.T., and Feinstein, D.T., 2003, Simulating ground water-lake interactionsApproaches and insights: Ground Water, v. 41, no. 2, p. 227-237.

Indian Health Service, 2009, Lac du Flambeau Community Wells, IHS Project No. BE-05-F06, [variously paged].

Juckem, P.F., and Fienen, M.N., 2013, Estimating prediction uncertainty with Monte Carlo techniques and analytic elements: Proceedings of the MODFLOW and More 2013 Conference, Golden, Colo.

Kelson, V.A., Hunt, R.J., and Haitjema, H.M., 2002, Improving a regional model using reduced complexity and parameter estimation: Ground Water, v. 40, no. 2, p. 138-149.

Kolpin, D.W., Furlong, E.T., Meyer, M.T., Thurman, E.M., Zaugg, S.D., Barber, L.B., and Buxton, H.T., 2002, Pharmaceuticals, hormones, and other organic wastewater contaminants in U.S. streams, 1990-2000: Environmental Science and Technology, v. 36, no. 6, p. 1202-1211, http://dx.doi. org/10.1021/es011055j.

Lenters, J.D., Kratz, T.K., Bowser, C.J., 2005, Effects of climate variability on lake evaporation: results from a longterm energy budget study of Sparkling Lake, northern Wisconsin (USA): Journal of Hydrology, v. 308, p. 168-195.

Markstrom, S.L., Niswonger, R.G., Regan, R.S., Prudic, D.E., and Barlow, P.M., 2008, GSFLOW-Coupled ground-water and surface-water flow model based on the integration of the Precipitation-Runoff Modeling System (PRMS) and the Modular Ground-Water Flow Model (MODFLOW-2005): U.S. Geological Survey Techniques and Methods book 6, chap. D1, 240 p.

Pint, C.D., Hunt, R.J., and Anderson, M.P., 2003, Flow path delineation and ground water age, Allequash Basin, Wisconsin: Ground Water, v. 41, no. 7, p. http://onlinelibrary.wiley. com/doi/10.1111/j.1745-6584.2003.tb02432.x/abstract.

Poeter, E.P., and Hill, M.C., 1997, Inverse models: a necessary next step in ground-water modeling: Ground Water, v. 35, no. 2, p. 250-260.
Reilly, T.E., and Pollock, D.W., 1993, Factors affecting areas contributing recharge to wells in shallow aquifers: U.S. Geological Survey Water-Supply Paper 2412, 21 p.

Robertson, D.M., Garn, H.S., Rose, W.J., Juckem, P.F., and Reneau, P.C., 2012, Hydrology, water quality, and response to simulated changes in phosphorus loading of Mercer Lake, Iron County, Wisconsin, with emphasis on effects of wastewater discharges on water quality: U.S. Geological Survey Scientific Investigations Report 2012-5134, 58 p.

Starn, J.J., and Bagtzoglou, A.C., 2012, Programs for calibration-based Monte Carlo simulation of recharge areas: Ground Water, v. 50, no. 3, p. 472-476.

U.S. Census Bureau, 2013, TIGER/Line Files, accessed November 20, 2013, at http://www.census.gov/geo/mapsdata/data/tiger-line.html.

U.S. Department of Agriculture, 2006, National Agricultural Imagery Program (NAIP) digital orthorectified images (DOQ), Wisconsin: accessed June 24, 2010, at http://datagateway.nrcs.usda.gov/.

U.S. Environmental Protection Agency, 2007, Cresol/Cresylic Acid, accessed September 14, 2012, at http://www.epa.gov/ ttnatw01/hlthef/cresols.html\#N_1.

U.S. Geological Survey, variously dated, National field manual for the collection of water-quality data: U.S. Geological Survey Techniques of Water-Resources Investigations, book 9, chaps. A1-A9. (Available at http://pubs.water.usgs.gov/ twri9A).

Westenbroek, S.M., Kelson, V.A., Dripps, W.R., Hunt, R.J., and Bradbury, K.R., 2010, SWB-A modified Thornthwaite-Mather Soil-Water-Balance code for estimating groundwater recharge: U.S. Geological Survey Techniques and Methods book 6, chap. A31, 60 p.

Wisconsin Department of Natural Resources, 2009, WI DNR 1:24,000-scale surface water hydrography: Wisconsin Department of Natural Resources geodatabase [computer file], accessed May 24, 2011, at ftp://dnrftp01.wi.gov/ geodata/hydro_24k/.

Wisconsin Department of Natural Resources, 2010, Water well data files: CD-ROM. 


\section{Appendix}

Results of water-quality analyses of samples collected from wells and surface water near wastewater-treatment lagoons, Lac du Flambeau Reservation, Wisconsin. 


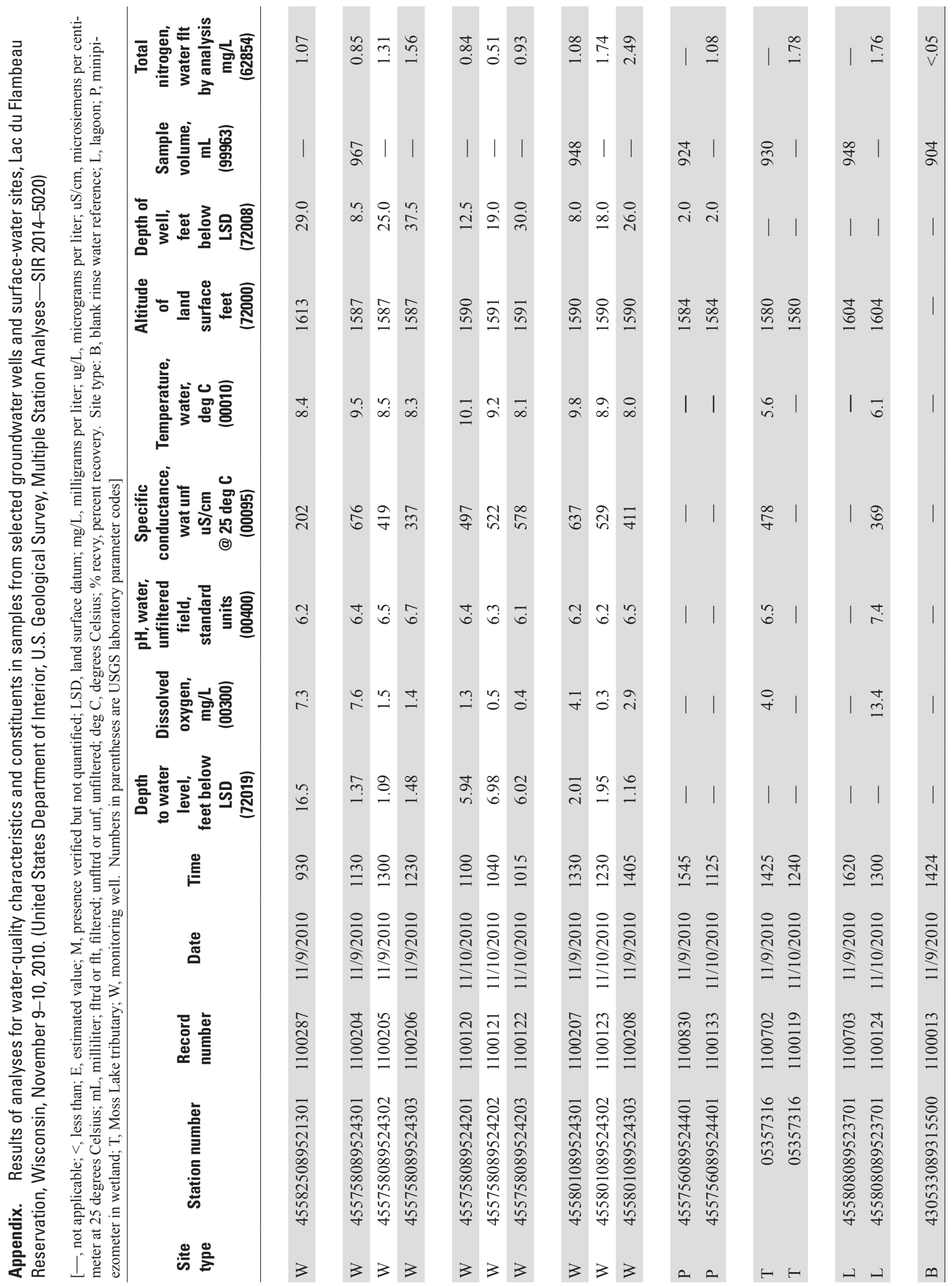




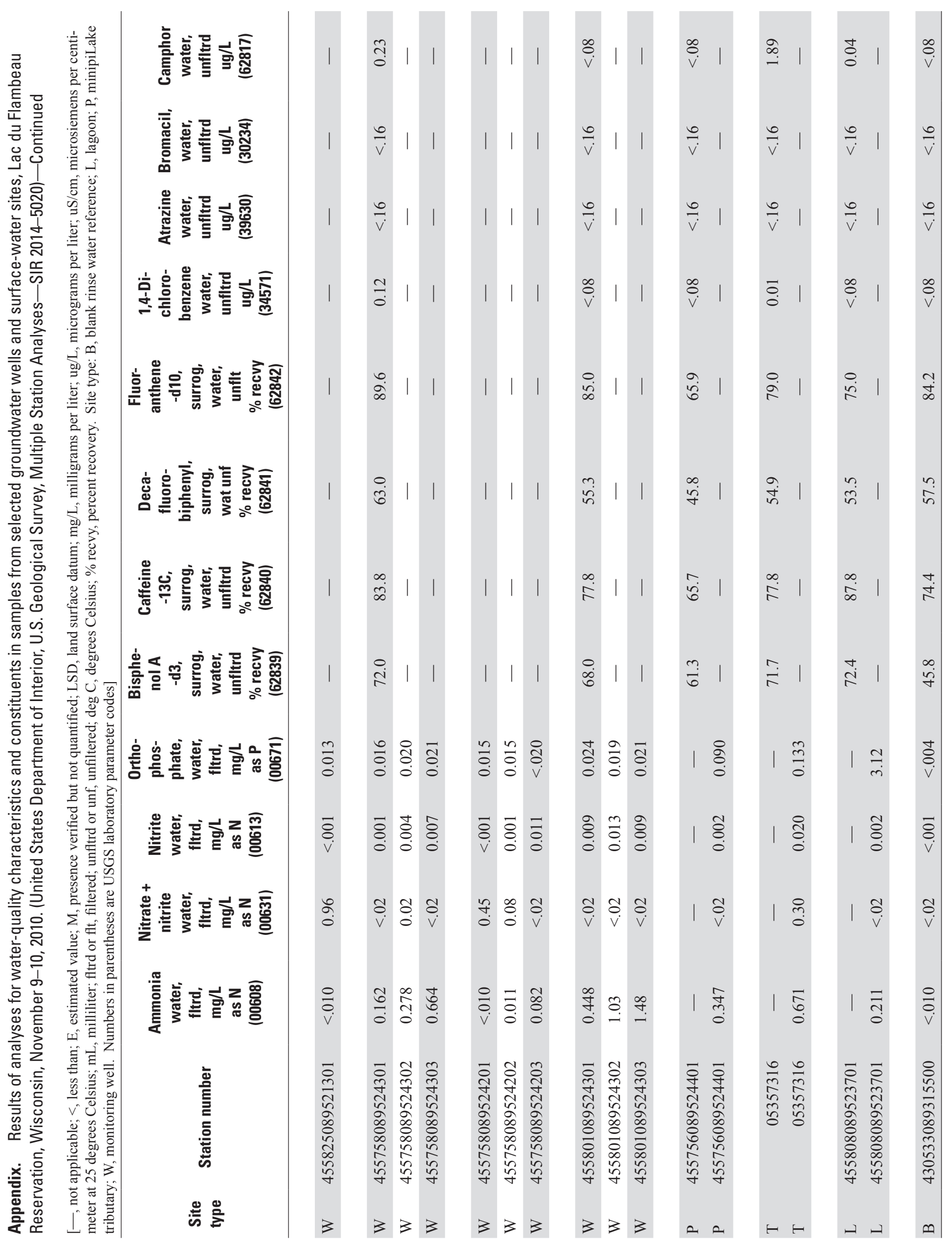




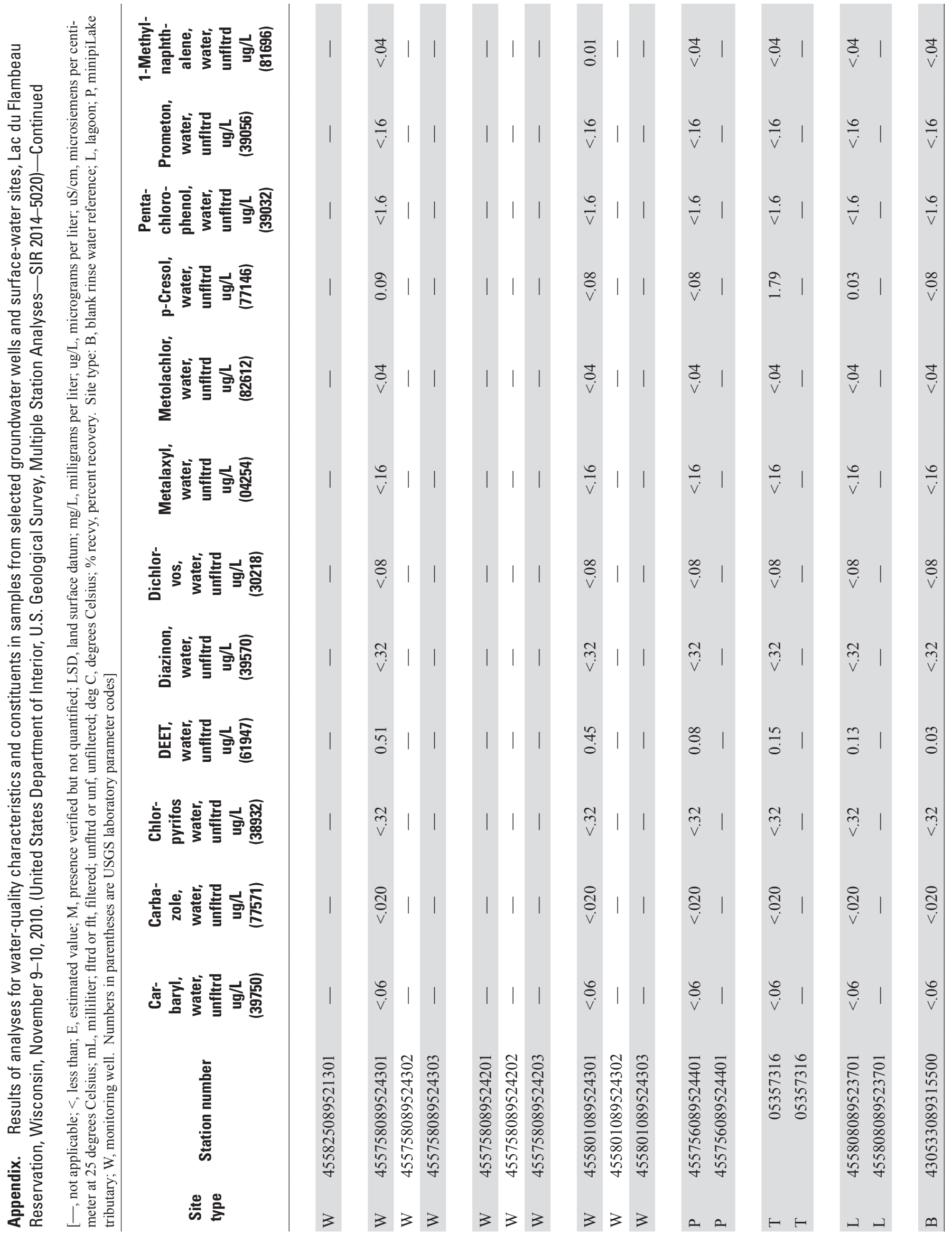




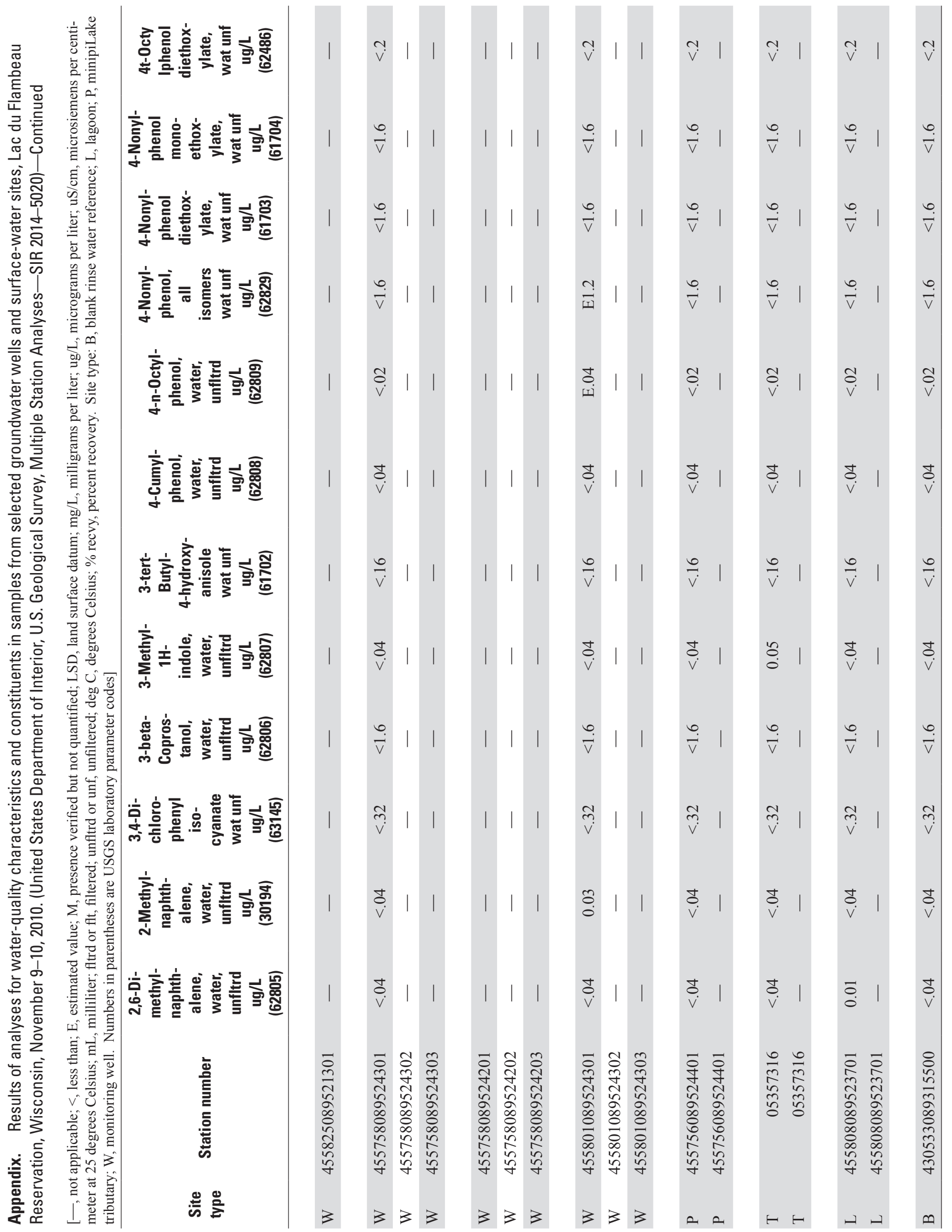




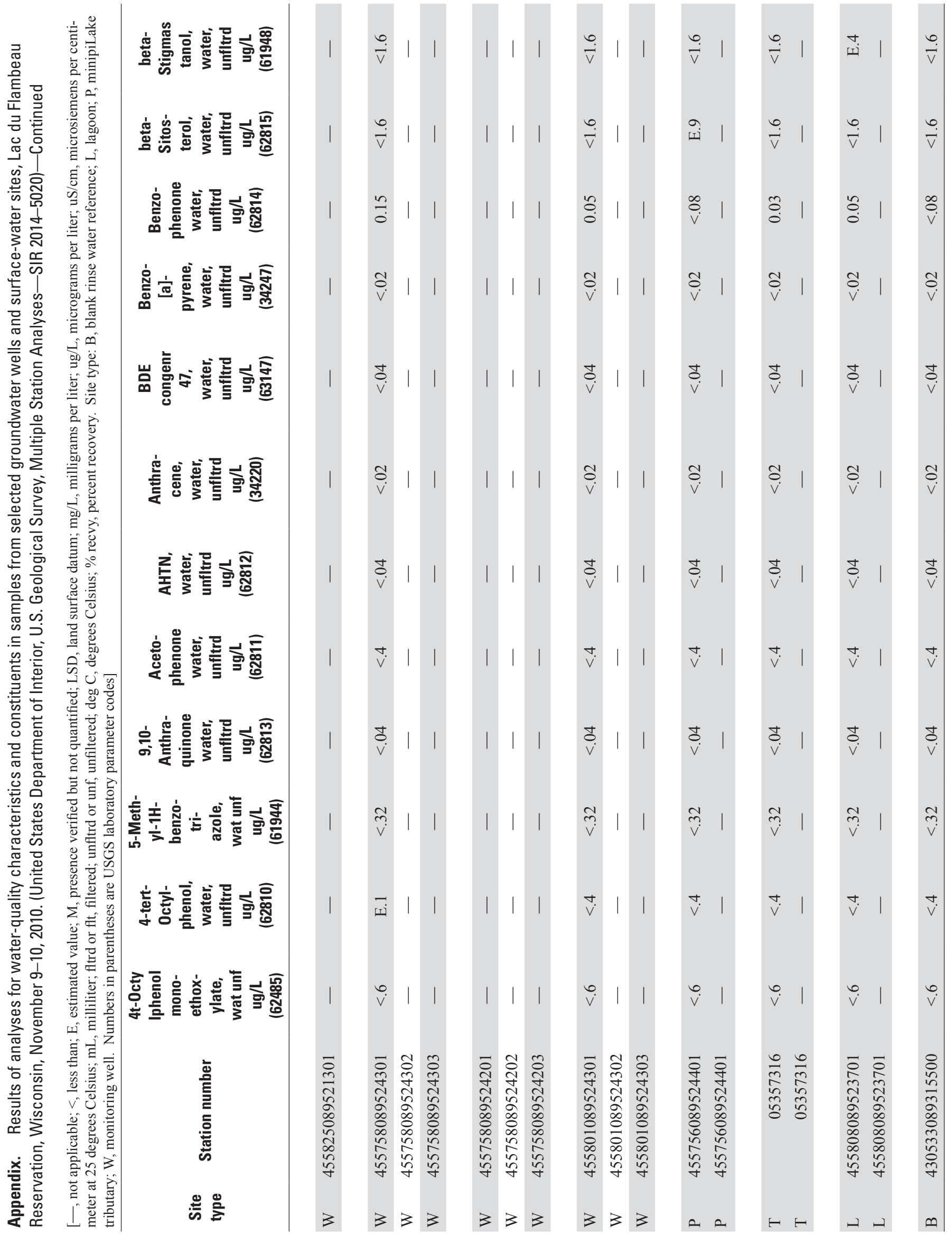




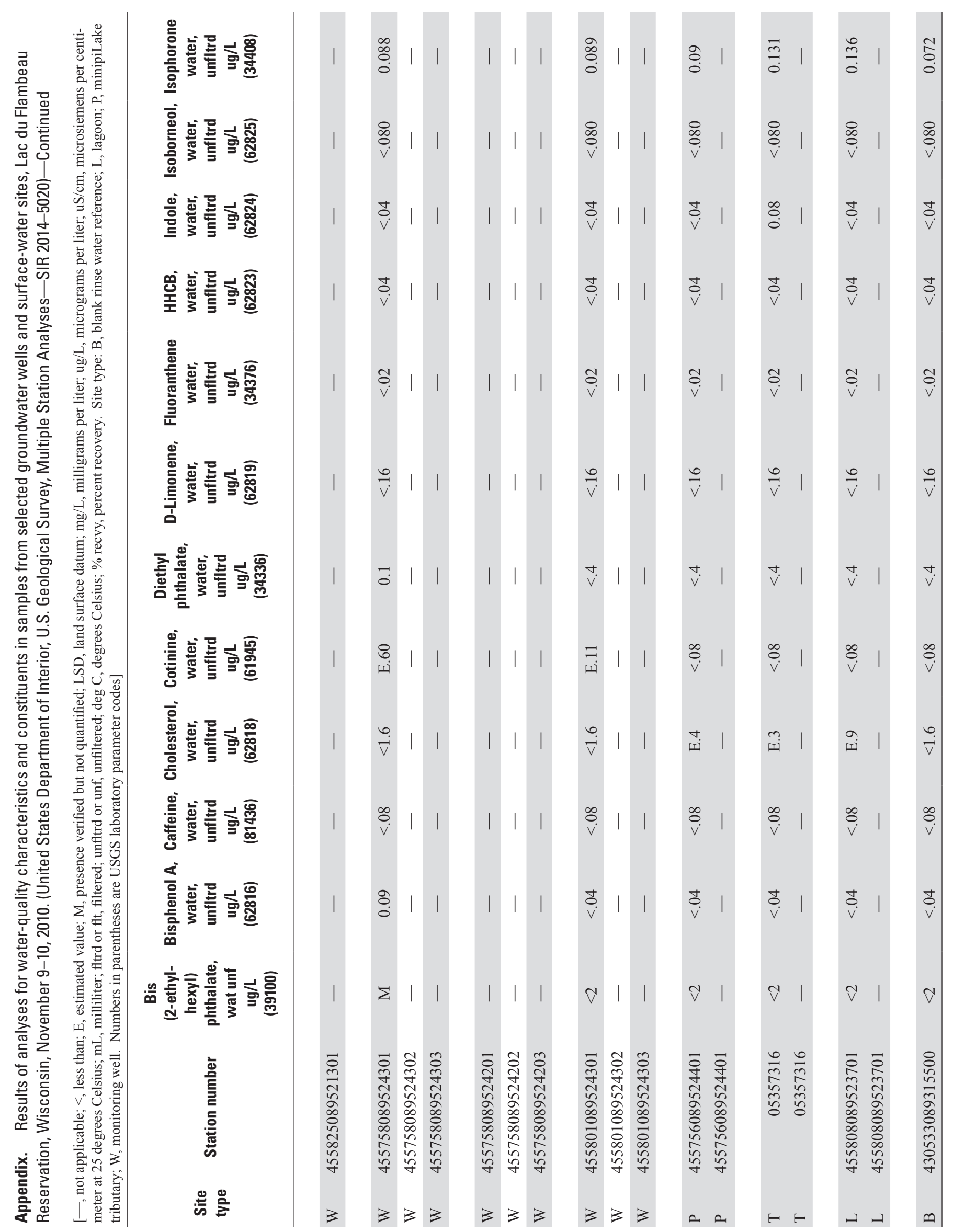




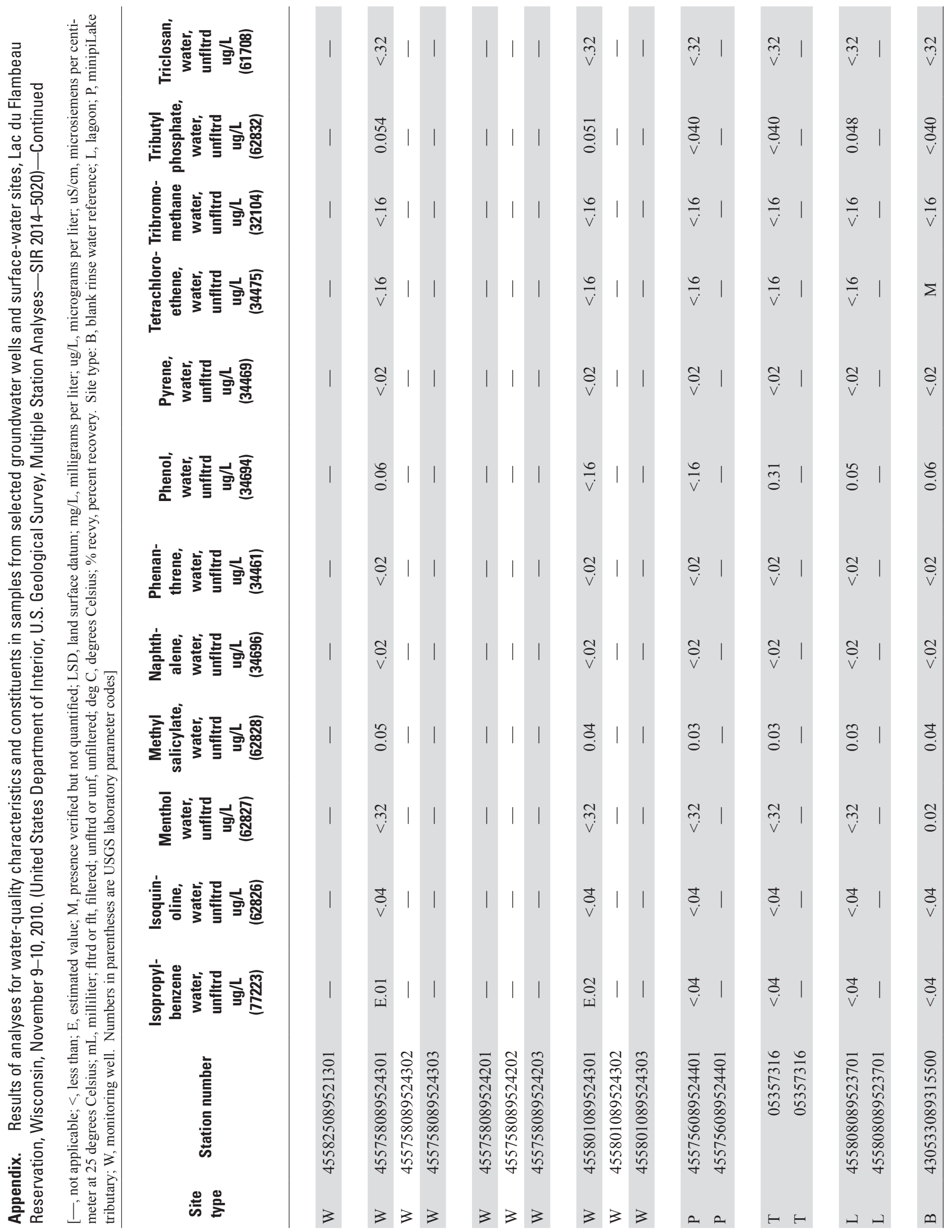




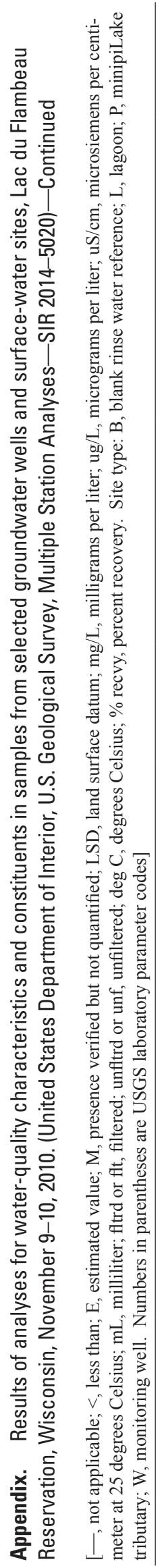

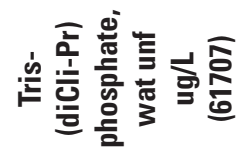

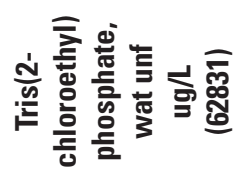

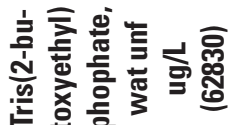

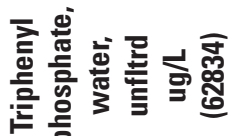

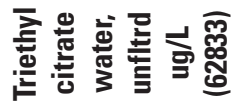

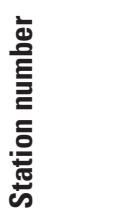

के

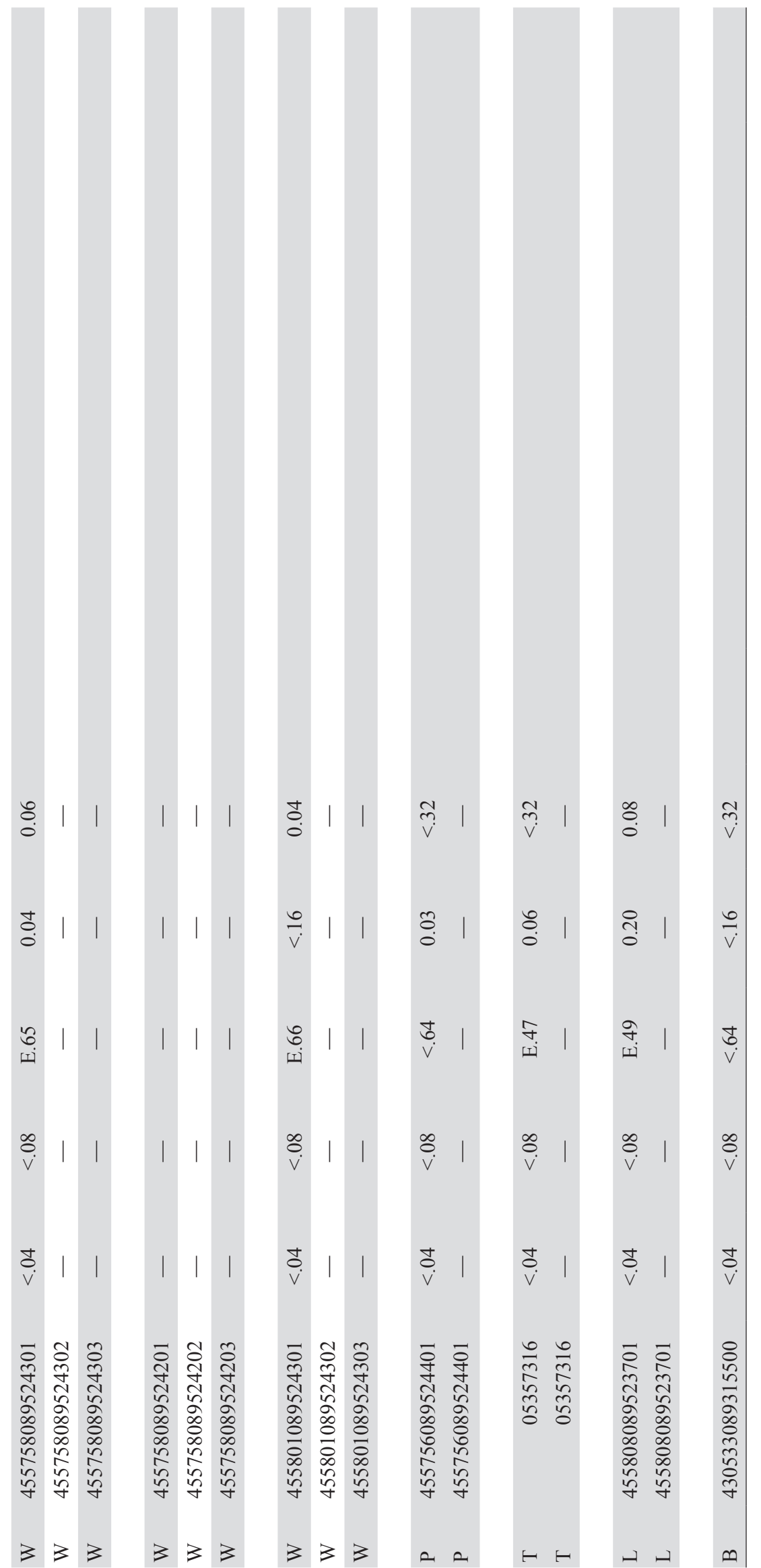




